\title{
Cranial Morphology and Adaptations in Eocene Adapidae. II. The Cambridge Skull of Adapis parisiensis
}

\author{
PHILIP D. GINGERICH AND ROBERT D. MARTIN \\ Museum of Paleontology, The University of Michigan, Ann Arbor, Michigan \\ 48109 (P.D.G.), and Department of Anthropology, University College London, \\ Gower Street, W.C. 1, London, U.K. (R.D.M.)
}

KEY WORDS Cranial anatomy, Eocene primates, Adapidae, Adapis, Brain size

\begin{abstract}
One of the most complete skulls of the early primate Adapis parisiensis is in the collection of the Department of Zoology, Cambridge University. This exceptionally well-preserved male skull, from Quercy in southern France, is important in showing relatively small orbits that are highly convergent, a distinct ethmoid component in the medial orbital wall, very small infraorbital foramina, a well-preserved auditory region with the stapedial canal about twice the diameter of the canal for the promontory artery, and a well-preserved braincase $8.8 \mathrm{~cm}^{3}$ in endocranial volume. The frontal lobe of the brain in the Cambridge skull described here is less expanded than that reported previously in a British Museum skull. The average body weight of Adapis parisiensis is estimated to have been about $2.0 \mathrm{~kg}$, and that of Adapis magnus is estimated to have been about 8.4 to $9.0 \mathrm{~kg}$. The encephalization quotient $(\mathrm{EQ})$ of Adapis parisiensis is estimated to have been 0.45 , which is well below the range found in modern prosimians. There is some indication that the size of the foramen magnum has increased with increasing brain size during primate evolution. Adapis parisiensis appears to have been a medium-sized, visually oriented, diurnal, sexually dimorphic arboreal folivore.
\end{abstract}

The first two specimens of Adapis parisiensis to be discovered, a crushed palate and associated mandible, were described by Cuvier in 1812. Some 60 years later, Delfortrie (1873) and Gervais (1873) recognized that Adapis is most similar, among living mammals, to lemuriform primates. Stehlin's (1912) extensive monograph on Adapis further substantiated this resemblance, as did Gregory's (1920) monograph on Notharctus. Stehlin illustrated several nearly complete skulls of both Adapis parisiensis and Adapis magnus, derived from the Quercy deposits of France, and discussed the phylogenetic history of European Adapidae in as much detail as was possible at that time.

Since 1912, relatively little has been added to our knowledge of the osteology of Adapis, but much additional dental material of Adapis and related genera has been collected and described by Stehlin (1916), Depéret (1917), Sudre (1969), Cray (1973), Schmidt-Kittler (1971), Crusafont-Pairo and Golpe-Posse (1975), von
Koenigswald (1979), and others. These new collections have much better stratigraphic documentation than the earlier assemblages from Quercy, and it is now possible to trace a probable evolutionary sequence in Europe from the large species Adapis magnus through an intermediate species, Adapis stintoni, to Adapis parisiensis (see Table 1 and Gingerich, 1981: Fig. 1). Adapis magnus is sometimes placed in a separate genus or subgenus "Leptadapis," but that seems unnecessary now that the phylogenetic relationships of the species involved are better documented.

Adapis parisiensis is poorly known postcranially, but some 20 or more skulls and partial skulls have been found, all collected during the nineteenth century from the Phosphorites $d u$ Quercy in France. When collected, these skulls were sold, along with other fossil specimens, to museums throughout Europe. As a result, some

\footnotetext{
Received March 11, 1981; accepted June 22, 1981.
} 
TABLE 1. Stratigraphic distribution of the species of Adapis considered in this paper

\begin{tabular}{|c|c|c|}
\hline Age & Species & Characteristics \\
\hline $\begin{array}{l}\text { Late Lattorfian } \\
\quad \text { (?Oligocene })^{1}\end{array}$ & Adapis parisiensis & $\begin{array}{l}\text { Small, with relatively } \\
\text { small canines }\end{array}$ \\
\hline $\begin{array}{l}\text { Early Lattorfian } \\
(\text { ?Oligocene })^{1}\end{array}$ & Adapis stintoni & $\begin{array}{l}\text { Intermediate, with } \\
\text { intermediate canines }\end{array}$ \\
\hline $\begin{array}{l}\text { Late Bartonian } \\
\text { (Eocene) }\end{array}$ & Adapis magnus & $\begin{array}{l}\text { Large, with moderate } \\
\text { canines }\end{array}$ \\
\hline
\end{tabular}

"The Lattorfian (= Priabonian) is placed in the early Oligocene by Berggren (1972) and others, while some include all pre-"Grande Coupure" mammalian faunas in the Eocene (Berggren et al., 1978).

of the best specimens were effectively hidden from study. In this paper we describe an exceptionally complete and well-preserved cranium of Adapis parisiensis now in the Museum of Zoology at Cambridge University. Our purpose is not to discuss phylogenetic relationships within Adapidae or between Adapidae and other primates. Rather we shall attempt to characterize the principal morphological features of the cranium of Adapis and interpret the adaptive significance of these by comparison with living primates.

\section{MATERIALS AND METHODS}

In order to make effective comparisons between Adapis species and modern primates, due consideration must be given to nonlinear scaling of various dimensions with body size, i.e., allometry (cf. Gould, 1966; Martin, 1980). Reference is therefore made in the following discussion to a number of studies conducted to relate different parameters (e.g., length of $M_{2}$, length multiplied by width of $\mathbf{M}^{1}$, orbital diameter, and cranial dimensions) to body size in samples of living primate species. Apart from data specifically mentioned in the text (Table 5; Figs. 4 and 5), the following reference material has been used:

(1) An analysis of the relationship between length of $M_{2}$ and body size in a sample of 38 extant noncercopithecoid species of primates, and length $\times$ width of $\mathbf{M}^{1}$ and body size in males and females of 41 primates, using average figures for several representatives of each species (Kay, 1975; Gingerich, 1977; Gingerich et al., 1981).

(2) An analysis of the relationship between various cranial dimensions and body size or brain size in a sample of 36 extant nonhuman primate species ( 18 lemurs and lorises, one tarsier, and 17 monkeys and apes). Cranial dimensions were, whenever possi- ble, averaged over eight skulls (four males, four females) for each species, while data on body and brain size were taken from Stephan et al. (1970), with a few modifications and additions (Martin, 1980).

(3) For analysis of relationships between cranial dimensions themselves, an enlarged sample of 48 extant nonhuman primate species (23 lemurs and lorises, one tarsier, and 24 monkeys and apes) was measured (Martin, 1980).

As a general rule, it is more appropriate to use the principal or major axis for describing allometric relationships, rather than the commonly utilized regression, as the former implies no distinction between dependent and independent variables in a bivariate plot. The major axis is used throughout the following discussion, except for the problem of predicting body weight from tooth size, where regression analysis is appropriate (Gingerich et al., 1981). Discrepancies between major axes and regressions decrease as the correlation coefficient $(r)$ increases, so with high $r$ values a regression will yield a result not greatly different from that obtained from the major axis.

\section{CRANIAL DIMENSIONS AND BODY SIZE}

The Cambridge skull of Adapis parisiensis, specimen no. M.538, is illustrated in Figures $1-3$. The skull is complete except for the crowns of the anterior teeth, an opening in the right side of the braincase, and the ventral surfaces of the auditory bullae. It is beautifully preserved, with even the cribriform plate and ethmoturbinals partially preserved. The skull appears to represent a relatively young individual, judging from the clear presence of many cranial sutures, although all teeth have erupted and the crowns still in place are slightly worn. The dental formula was clearly 2.1.4.3. 

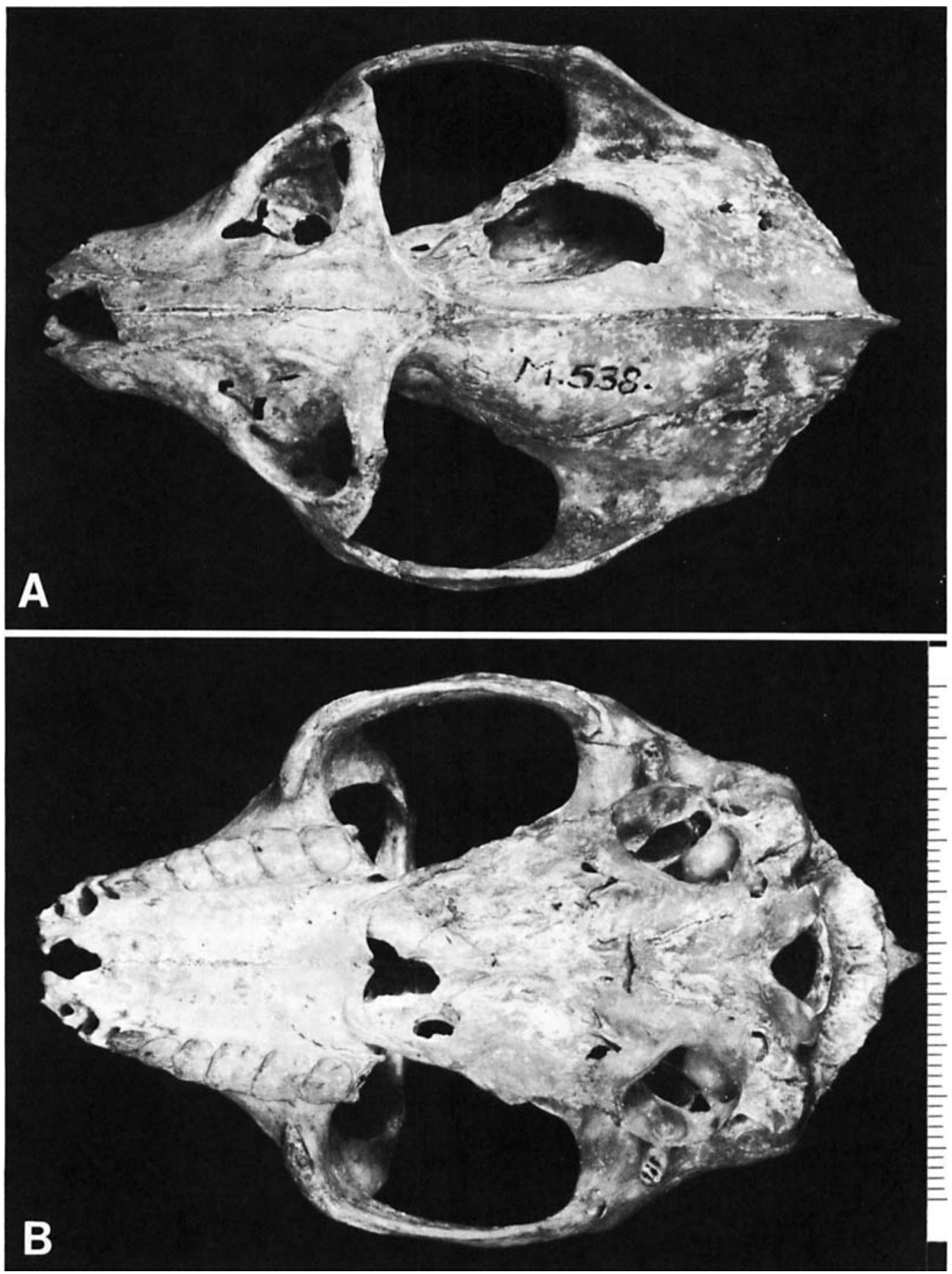

Fig. 1. Cambridge skull of Adapis parisiensis (M.538) in dorsal (A) and ventral (B) views. Note damage to right temporal area and preparatory removal of the ventral floor of both bullae. Scale in $\mathrm{mm}, 1.5 \times$ natural size. 

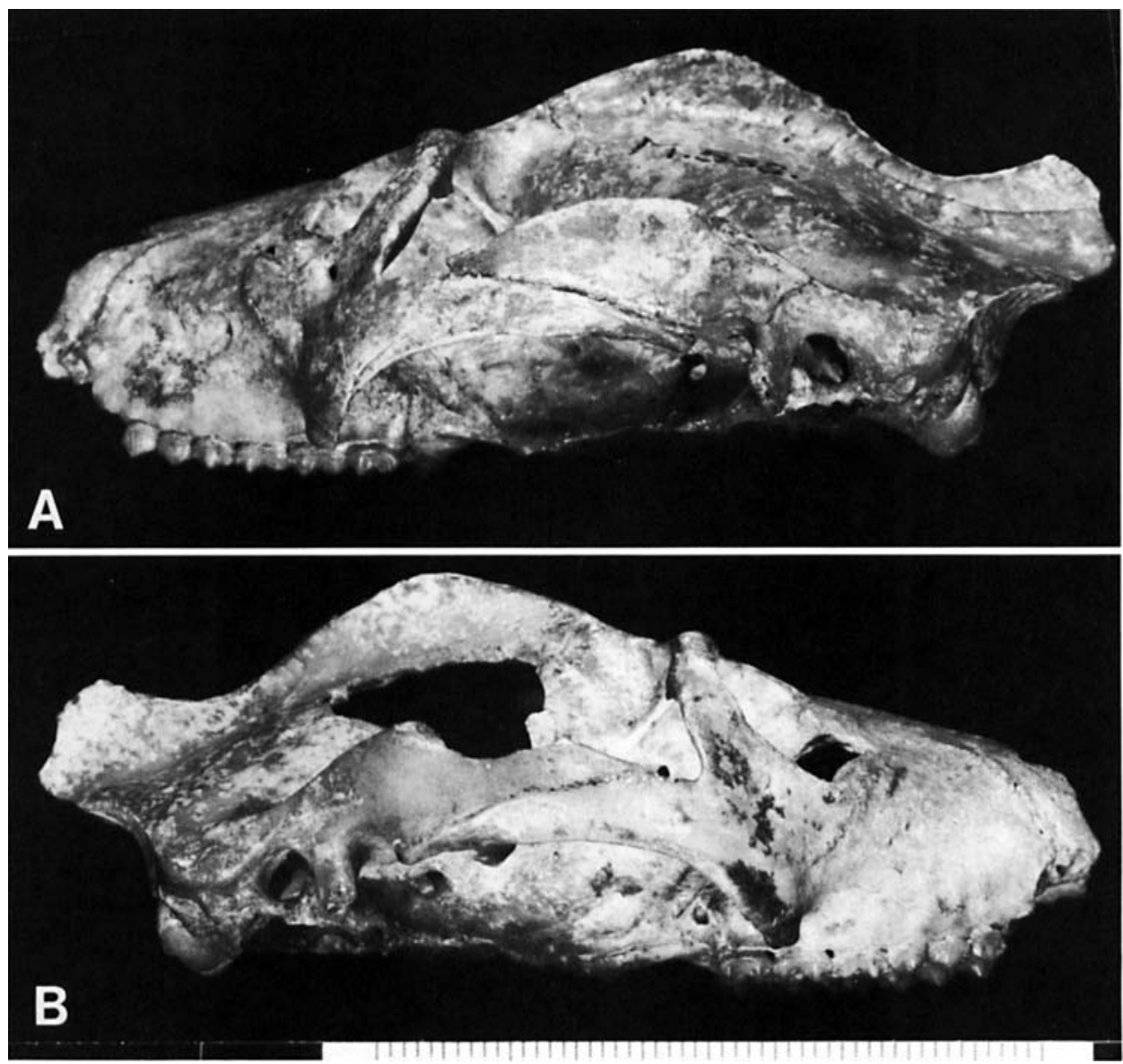

Fig. 2. Cambridge skull of Adapis parisiensis (M.538) in left lateral (A) and right lateral (B) views. Scale in mm, $1.5 \times$ natural size.

Judging from other skulls of this species preserving the anterior teeth (represented only by alveoli in the Cambridge skull), the upper central incisors were slightly larger than the lateral ones and their crowns converged markedly toward the midline of the skull, as in Propithecus among living lemuroids and Saimiri among anthropoids (Fig. 4). Left and right central incisors actually contacted each other distally, but the roots and proximal parts of the incisor crowns were separated, leaving a median gap. This median gap may have permitted a naked rhinarium to connect directly to Jacobson's organ, as in living Microcebus (Schilling, 1970; Martin, 1973). On the other hand, some ceboids (Saimiri) have convergent upper central incisors with a similar (although definitely smaller) median gap. Thus we cannot be sure that the nasal structure of Adapis was anatomically or functionally like that in modern strepsirhine primates. Ceboidea usually have a functional Jacobson's organ (Maier, 1981), although they do not have a naked rhinarium. In addition, some ceboids have a median furrow in the upper lip possibly representing a vestige of the schizocheilic labial cleft characteristic of lemuriform primates (Hofer, 1980).

The upper canine teeth are also not preserved in the Cambridge skull, but by comparison with other specimens of Adapis parisiensis we can infer that they were probably short-crowned (see for example Stehlin, 1912: Figs. 244 and 254; Gingerich, 1981: Fig. 5). Premolar and molar morphology of this species is well known; 


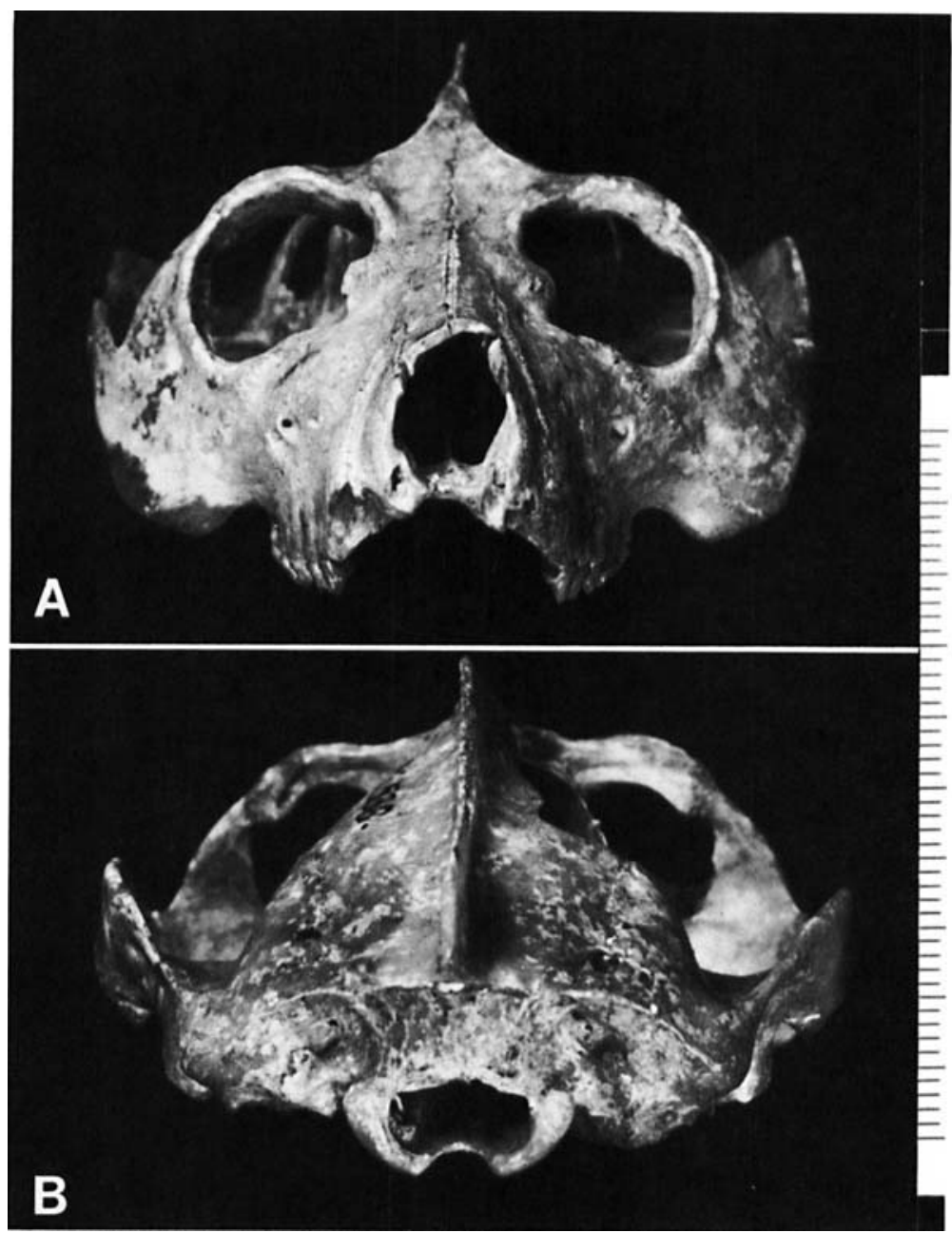

Fig. 3. Cambridge skull of Adapis parisiensis (M.538) in anterior (A) and posterior (B) views. Note the median gap (partially broken) between anterior incisor alveoli. Scale in $\mathrm{mm}, 1.5 \times$ natural size.

the last premolars are partly molarized, and the true molars are relatively simple quadrate teeth similar to those of Lepilemur or Hapalemur in structure. The pointed and crested morphology of the molars of Adapis (Gingerich, 1972) suggests that it was predominantly folivorous, as are Lepilemur (Hladik and Charles-Dominique, 1974) and Hapalemur (Petter and Peyrieras, 1970; see also Petter et al., 1977).

Cranial and dental dimensions of the Cambridge Adapis skull are given in Table 2. For comparison, dental and cranial measurements are also given for two additional skulls of $A d a-$ pis parisiensis preserved in the British $\mathrm{Mu}$ seum (Natural History). To place these skulls in perspective, a logarithmic plot of skull length versus skull width is shown in Figure 5. Basal skull length (or "condylobasal length"front of incisors to back of occipital condyles) and skull width can be measured or estimated reliably in a total of ten skulls of Adapis parisiensis. These are plotted in Figure 5 and, interestingly, they cluster into two distinct groups. None of the extant species plotted shows any tendency to separate into distinct groups, even 

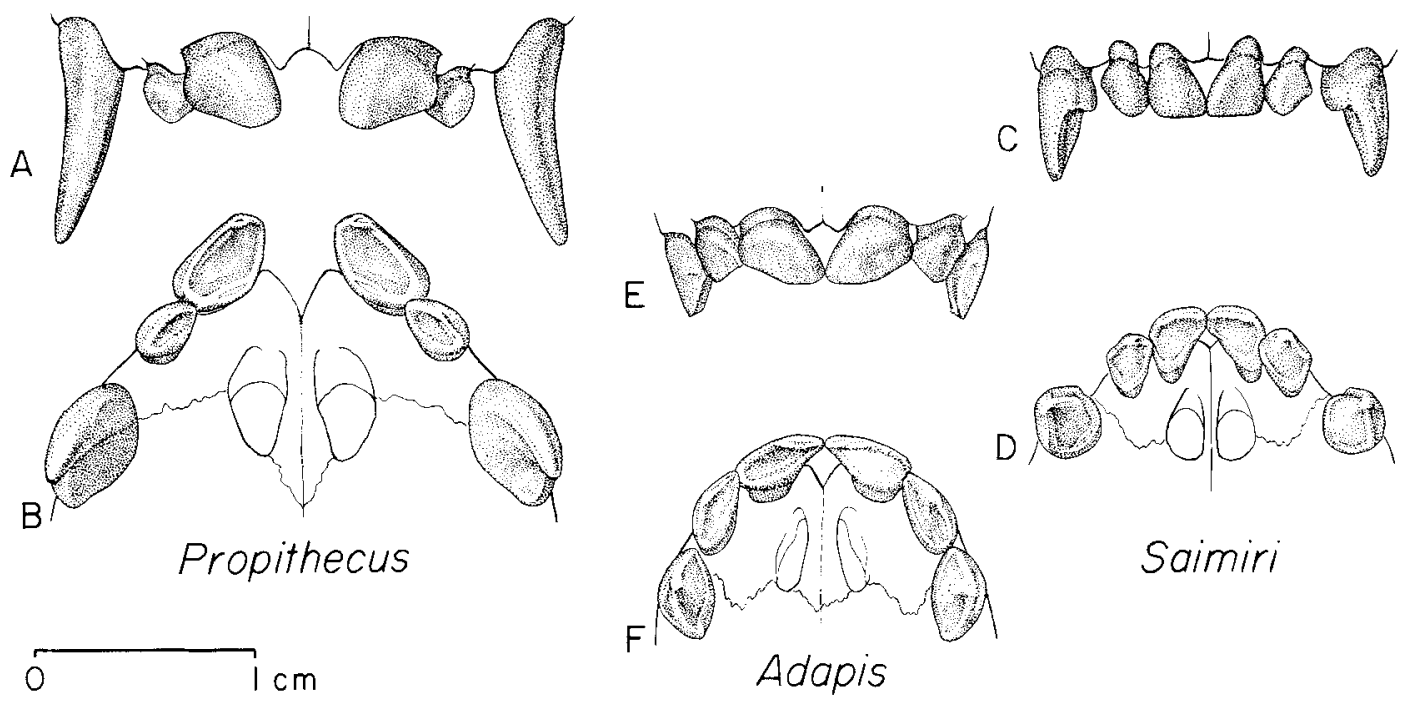

Fig. 4. Upper incisors and canines of extantPropithecus verreauxi (A, B) and Saimiri sciureus (C, D) compared with those of $A$ dapis parisiensis (E, F). In each case, upper figure is anterior view and lower figure is occlusal view. Note the large median gap between left and right central incisors in Propithecus. Adapis resembles Saimiri in having a smaller median gap, with central incisors contacting at the midline. Adapis parisiensis drawn from Montauban-6 (left central incisor reversed from right side; presence of an interproximal wear facet indicates that upper central incisors contacted each other in life).

TABLE 2. Dental and cranial measurements of Cambridge and British Museum (Natural History) skulls of Adapis parisiensis (in $\mathrm{mm}$ )

\begin{tabular}{|c|c|c|c|c|c|c|}
\hline \multirow[b]{3}{*}{ Tooth } & \multirow{2}{*}{\multicolumn{2}{|c|}{$\begin{array}{l}\text { Cambridge } \\
\text { M.538 (male) }\end{array}$}} & \multicolumn{4}{|c|}{ British Museum } \\
\hline & & & \multicolumn{2}{|c|}{ M.1345 (male) } & \multicolumn{2}{|c|}{ M.1633 (female) } \\
\hline & $\mathrm{L}$ & W & $\mathrm{L}$ & W & L & $\mathrm{W}$ \\
\hline $\mathrm{C}^{1}$ & - & - & 4.4 & 3.2 & 3.5 & 2.2 \\
\hline $\mathrm{P}^{2}$ & 4.1 & 2.6 & 3.9 & 2.4 & 3.4 & 2.1 \\
\hline $\mathbf{P}^{3}$ & 4.3 & 3.0 & 4.0 & 2.6 & 3.4 & 2.3 \\
\hline $\mathrm{P}^{4}$ & 3.8 & 4.3 & 4.0 & 4.0 & 3.6 & 3.7 \\
\hline $\mathbf{M}^{1}$ & 4.5 & 4.9 & 4.4 & 4.5 & 4.1 & 4.5 \\
\hline $\mathbf{M}^{2}$ & 4.8 & 5.0 & 4.6 & 4.9 & 4.5 & 4.7 \\
\hline $\mathbf{M}^{3}$ & 4.0 & 4.8 & 4.6 & 4.8 & 4.1 & 4.7 \\
\hline \multicolumn{2}{|c|}{$\begin{array}{l}\text { Skull length } \\
\text { (condylobasal length) }\end{array}$} & $75.5^{*}$ & \multicolumn{2}{|r|}{$75.0^{*}$} & \multicolumn{2}{|c|}{65.0} \\
\hline \multicolumn{2}{|c|}{ Maximum skull length } & $84.0^{*}$ & \multicolumn{2}{|r|}{$85.0^{*}$} & \multicolumn{2}{|c|}{-} \\
\hline \multicolumn{2}{|c|}{$\begin{array}{l}\text { Maximum skull breadth } \\
\text { (bizygomatic) }\end{array}$} & 55.5 & \multicolumn{2}{|r|}{54.5} & \multicolumn{2}{|c|}{$45.0^{*}$} \\
\hline \multicolumn{2}{|c|}{ Interorbital breadth } & 10.9 & \multicolumn{2}{|r|}{$11.0^{*}$} & \multicolumn{2}{|c|}{ - } \\
\hline \multicolumn{2}{|c|}{$\begin{array}{l}\text { Zygomatic length } \\
\text { (internal) }\end{array}$} & 23.4 & \multicolumn{2}{|r|}{22.8} & \multicolumn{2}{|c|}{-} \\
\hline \multicolumn{2}{|c|}{ Orbital diameter } & 14.2 & \multicolumn{2}{|r|}{13.7} & \multicolumn{2}{|c|}{13.0} \\
\hline \multicolumn{2}{|c|}{$\begin{array}{l}\text { Sagittal crest } \\
\text { height }\end{array}$} & 9.0 & \multicolumn{2}{|r|}{7.0} & \multicolumn{2}{|c|}{-} \\
\hline \multicolumn{2}{|c|}{$\begin{array}{l}\text { Foramen magnum } \\
\text { height }\end{array}$} & 7.0 & \multicolumn{2}{|r|}{7.0} & & \\
\hline Forame & & 8.9 & & 8.5 & & \\
\hline $\begin{array}{l}\text { Condyl } \\
\text { (heig }\end{array}$ & & $\begin{array}{l}8.4 \times 3.3 \\
\quad=27.7\end{array}$ & & $\begin{array}{l}7.9 \times 4.3 \\
=34.0\end{array}$ & & \\
\hline
\end{tabular}

*Estimated measurement. 


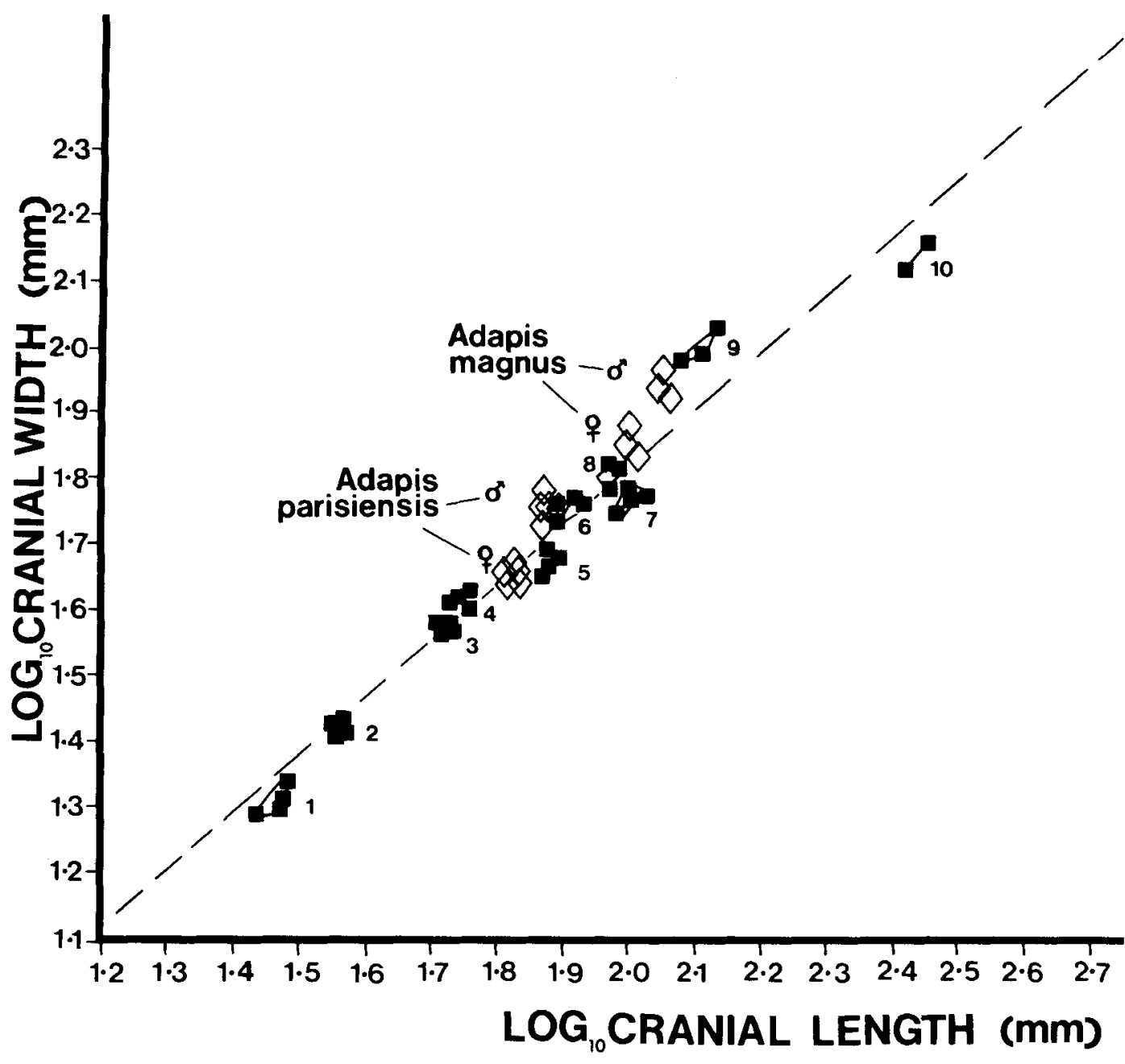

Fig. 5. Logarithmic plot of bizygomatic cranial width against condylobasal cranial length in living and subfossil lemur species (solid squares), using mixed groups of males and females for each of the living species. The dashed line is the major axis for the living species: $\log _{10} \mathrm{SW}=0.89 \log _{10} \mathrm{SL}$ +0.04 (where $\mathrm{SL}=$ cranial length; $\mathrm{SW}=$ cranial width, and $r$ $=0.98$ ). Open diamonds are Adapis. Note distinctly dimor-

though the specimens plotted for each extant species include both males and females in every case. This suggests that Adapis parisiensis was probably a sexually dimorphic primate species. The cheek teeth in all of these specimens are very similar in size and shape, and there is no evidence of temporal or spatial separation of the two forms in the fossil record. Differences in relative canine size and the development of sagittal and nuchal crests further substantiate phic clustering of each Adapis species, contrasting with the monomorphic clustering of living lemur species (see text). Key: (1) Microcebus murinus, (2) Cheirogaleus medius, (3) Lepilemur mustelinus, (4) Hapalemur griseus, (5) Lemur catta, (6) Propithecus diadema, (7) Varecia variagata (8) Indri indri, (9) Archaeolemur sp., (10) Megaladapis edwardsi.

that the two clusters separate males and females (Gingerich, 1981). According to this interpretation, the Cambridge skull and the British Museum skull M.1345 are both males of Adapis parisiensis, whereas British Museum M.1633 is a female. Basal skull length and skull width can be measured on a total of seven skulls of Adapis magnus, and these also cluster into two distinct groups. Relatively large canine teeth and large sagittal and nuchal crests 
TABLE 3. Body weight estimates for Adapis parisiensis and Adapis magnus based on cranial measurements (see text)

\begin{tabular}{|c|c|c|c|c|c|}
\hline \multirow[b]{2}{*}{ Specimen } & \multicolumn{4}{|c|}{ Body weight estimates (gm) } & \multirow{2}{*}{$\begin{array}{l}\text { Average } \\
\text { individual } \\
\text { estimate } \\
\text { (gm) }\end{array}$} \\
\hline & SL & $\mathbf{B Z}$ & IZ & $(\mathrm{COW} \times \mathrm{COL})$ & \\
\hline \multicolumn{6}{|l|}{ Adapis parisiensis" } \\
\hline Cambridge M.538 (male) & 2,500 & 2,400 & 3,200 & 1,300 & 2,350 \\
\hline BMNH M.1345 (male) & 2,600 & 2,300 & 2,900 & 2,000 & 2,450 \\
\hline \multicolumn{6}{|l|}{ Adapis magnus ${ }^{2}$} \\
\hline Paris 10870 (male) & 9,400 & 14,000 & 17,000 & 5,700 & 11,500 \\
\hline Paris 10875 (female) & 6,000 & 6,600 & 7,900 & 7,100 & 6,900 \\
\hline Paris 10872 (female) & 5,300 & - & - & 7,000 & 6,150 \\
\hline Paris 11002 (sex indet.) & 7,000 & - & - & 4,200 & 5,600 \\
\hline
\end{tabular}

again support interpretation of the larger specimens as males and the smaller specimens as females of Adapis magnus.

Male Adapis parisiensis skulls, including Cambridge M.538, are about the same length as those of Lemur catta (species 5 in Fig. 5), but they are somewhat broader. Martin (1973) compared British Museum M.1345 with the skull of Lemur mongoz, and estimated the weight of Adapis parisiensis to have been about $1.5 \mathrm{~kg}$. Jerison (1973: p. 379) estimated the weight of Adapis parisiensis as $1.6 \mathrm{~kg}$, based on an independent comparison with Lemur mongoz. Radinsky (1977) estimated the weight of Adapis parisiensis as $2.5 \mathrm{~kg}$, taking an average of body weights for Lemur mongoz and Propithecus verreauxi (near species 6 in Fig. 5). Finally, Jerison (1979) gave a revised estimate of $1.7 \mathrm{~kg}$, based on comparison of cranial length in A. parisiensis with that in a range of living prosimians. Using a regression of body weight (BW) on the length of $\mathrm{M}_{2}$ (LM) for 38 extant noncercopithecoid primate species (Gingerich, 1977), we initially estimated an average body weight for Adapis parisiensis of about $2.2 \mathrm{~kg}$ $\left(\log _{10} \mathrm{BW}=3.29 \log _{10} \mathrm{LM}+1.10 ; r=0.96\right)$, but this does not take into account the fact that folivores have longer, narrower teeth than generalized primates. The average body weight calculated from both length and width of $\mathrm{M}^{1}$ of Adapis parisiensis, based on the values given in Table 2, is $2.0 \mathrm{~kg}$ (Gingerich et al., 1981), and this is a more reliable estimate than that based on tooth length alone.

A more comprehensive approach, meeting the criticism made by Radinsky (1977), is to examine the relationship between a number of different skull measures and body weight for a large sample of primate species $(\mathrm{N}=36$; Martin, 1980). Analyses of allometric relationships indicate that, when they are preserved, the following parameters can be used in addition to tooth size for estimating body size (based on major axes of double $\log _{10}$ plots):

(1) Maximum skull length (SL):

$\log _{10} \mathrm{BW}=3.89 \log _{10} \mathrm{SL}-4.09[r=0.98](1)$

(2) Bizygomatic width (BZ):

$\log _{10} \mathrm{BW}=3.77 \log _{10} \mathrm{BZ}-3.19[r=0.98](2)$

(3) Internal zygomatic length (IZ):

$\log _{10} \mathrm{BW}=3.26 \log _{10} \mathrm{IZ}-0.96[r=0.96]$ (3)

(4) Condylar area (COW $\times$ COL):

$\log _{10} \mathrm{BW}=2.16 \log _{10}(\mathrm{COW} \times \mathrm{COL})[\mathrm{r}=0.98](4)$

where internal zygomatic length (IZ) is measured as the maximal anteroposterior length of the temporal fossa within the zygomatic arch, and condylar area (COW $\times \mathrm{COL})$ is measured as the product of the maximum length and the maximum width of one occipital condyle.

In order to test the reliability of these measures as indicators of body weight, values were estimated from the four skull parameters for a panel of 12 primate species not included in the original sample. Averages of the estimations for each species are in fairly good agreement with actual body weights (Martin, 1980: Table 2 ), except in three cases where strong sexual dimorphism is present (Papio, Theropithecus, and Pongo) and skull dimensions lead to an 
TABLE 4. Cranial length and oroital diameter in extant lemurs ${ }^{1}$

\begin{tabular}{|c|c|c|}
\hline Species & Cranial Length (mm) & Orbital diameter ( $\mathrm{mm})$ \\
\hline \multicolumn{3}{|c|}{ A. Fully nocturnal species } \\
\hline 1. Microcebus murinus & 28.9 & 9.6 \\
\hline 2. Cheirogalens medius & 37.0 & 11.1 \\
\hline 3. Microcebus coquereli & 45.6 & 12.9 \\
\hline 4. Phaner furcifer & 49.4 & 13.9 \\
\hline 5. Cheirogalens major & 51.4 & 14.6 \\
\hline 6. Lepilemur mustelinus & 53.0 & 15.6 \\
\hline 7. Avahi laniger & 48.9 & 17.0 \\
\hline 8. Daubentonia madagascariensis & 74.4 & 20.3 \\
\hline \multicolumn{3}{|c|}{ B. Intermediate or fully diurnal species } \\
\hline 9. Hapalemur griseus & 55.7 & 16.1 \\
\hline 10. Lemur mongoz & 70.8 & 18.2 \\
\hline 11. Lemur catta & 75.9 & 17.6 \\
\hline 12. Lemur rubriventer & 77.5 & 19.5 \\
\hline 13. Lemur macaco & 82.3 & 18.9 \\
\hline 14. Hapalemur simus & 73.0 & 20.3 \\
\hline 15. Varecia variegatus & 99.5 & 21.3 \\
\hline 16. Propithecus verreauxi & 75.2 & 19.5 \\
\hline 17. Propithecus diadema & 78.3 & 21.8 \\
\hline 18. Indri indri & 94.6 & 22.9 \\
\hline
\end{tabular}

'Numbers at left refer to points in Figure 6. Data from skulls measured by Gingerich at the British Museum (Natural History) in London and at the Rijksmuseum van Natuurlijke Historie in Leiden. Figures represent averages for four specirzens in all cases except Hapalemur simus $(\mathrm{N}=1)$. Cranial length = condylobasal length measured from front of incisors or premaxillae to back of occipital condyles; orbital diameter = average of orbital height and orbital width. Activity patterns from Martin (1972), but note that Tattersall and Sussman (1975) found Lemur mongoz to be nocturnal in N. W. Madagascar, whereas Tattersall (1978) reports diurnal activity in this species on one of the Comoro Islands.

overestimation of body weight averaged between the sexes.

When the above relationships are applied to the appropriate skull dimensions of Adapis species, overall estimates of $2.4 \mathrm{~kg}$ for Adapis parisiensis and $9.0 \mathrm{~kg}$ for Adapis magnus are obtained (Table 3). The estimates for Adapis parisiensis are based on skulls that are probably both males, and thus the figure of $2.4 \mathrm{~kg}$ exaggerates the average weight of the species as a whole. In modern strongly sexually dimorphic species, even the average dimensions of males and females yield an overestimation of the average body weight of a species (see above).

Considering all of the estimates based on comparative data from large samples of extant primate species, a figure of $2.3-2.4 \mathrm{~kg}$ is probably the most appropriate for the body weight of male Adapis parisiensis. Female A. parisiensis probably weighed about $1.6-1.7 \mathrm{~kg}$ (Gingerich, 1981), and the average weight of the species was about $2.0 \mathrm{~kg}$. This is in agreement with the average body size predicted from tooth size when both length and width of upper or lower first molars are taken into account, and this matches the value of $2.0 \mathrm{~kg}$ given for Lemur catta by Bauchot and Stephen (1966). Lemur catta may safely be used as an approximate model for the body size of Adapis parisiensis, but it must be remembered that male and fe- male Adapis were significantly different in body size.

A note must be added here on the use of foramen magnum area as an indicator of body size. Radinsky (1970) used foramen magnum area as a basis for analyzing brain:body size relationships in living prosimians and Adapis parisiensis. He implied that the latter had the same relative brain size as recent prosimians, since it fell within the modern range in a plot of endocranial volume against foramen magnum area. This interpretation was subsequently questioned by Jerison (1973), Martin (1973), and Gould (1975), on the grounds that foramen magnum area may be linked with brain size itself, rather than simply reflecting body size. Radinsky (1977) subsequently confirmed that this is, indeed, the case and indicated that Adapis probably had a brain/body size relationship inferior to the range covered by modern prosimians. Taking the sample of 36 modern nonhuman primate species mentioned above, the major axis for the relationship between logarithmic values for foramen magnum area (FA) and body weight (BW) was found to have the following formula:

$$
\log _{10} \mathrm{FA}=0.47 \log _{10} \mathrm{BW}+0.56[r=0.98]
$$

The average body weights estimated for Adapis parisiensis $(\mathrm{N}=2)$ and Adapis magnus $(\mathrm{N}=4)$ from this formula are only $409 \mathrm{gm}$ and $807 \mathrm{gm}$, 
respectively. Thus foramen magnum area gives a far lower estimate of body size compared to all other measures. An important practical implication of this finding is that Adapis species exhibited a much smaller foramen magnum area (relative to body size) than any modern prosimian species (see below).

\section{ORBITAL SIZE AND CONSTRUCTION}

An obvious feature of the skull of Adapis parisiensis shown in Figures 1-3 is its high degree of orbital convergence (approximately $65^{\circ}$; measured as outlined by Cartmill, 1971), indicating that vision was an important sensory modality. The average diameters of the orbits in the Cambridge and British Museum skulls of Adapis parisiensis are given in Table
2. These range from 13.0 to $14.2 \mathrm{~mm}$. For comparison, orbital diameter and condylobasal skull length were measured in eight definitely nocturnal and ten intermediate or definitely diurnal Malagasy lemuroids (Table 4). All of these values are plotted on logarithmic scales in Figure 6. Living lemuroids cluster into two distinct groups, one small and mostly nocturnal (Microcebus, Avahi, etc.), and the other larger and mostly diurnal (most Lemur, Propithecus, etc.). The obvious exceptions on grounds of body size are the relatively small Hapalemur griseus (no. 9 in Fig. 6), which is diurnal or crepuscular, and the larger Daubentonia madagascariensis (no. 8 in Fig. 6), which is nocturnal. According to Tattersall and Sussman (1975), Lemur mongoz in Madagascar is nocturnal and thus an-

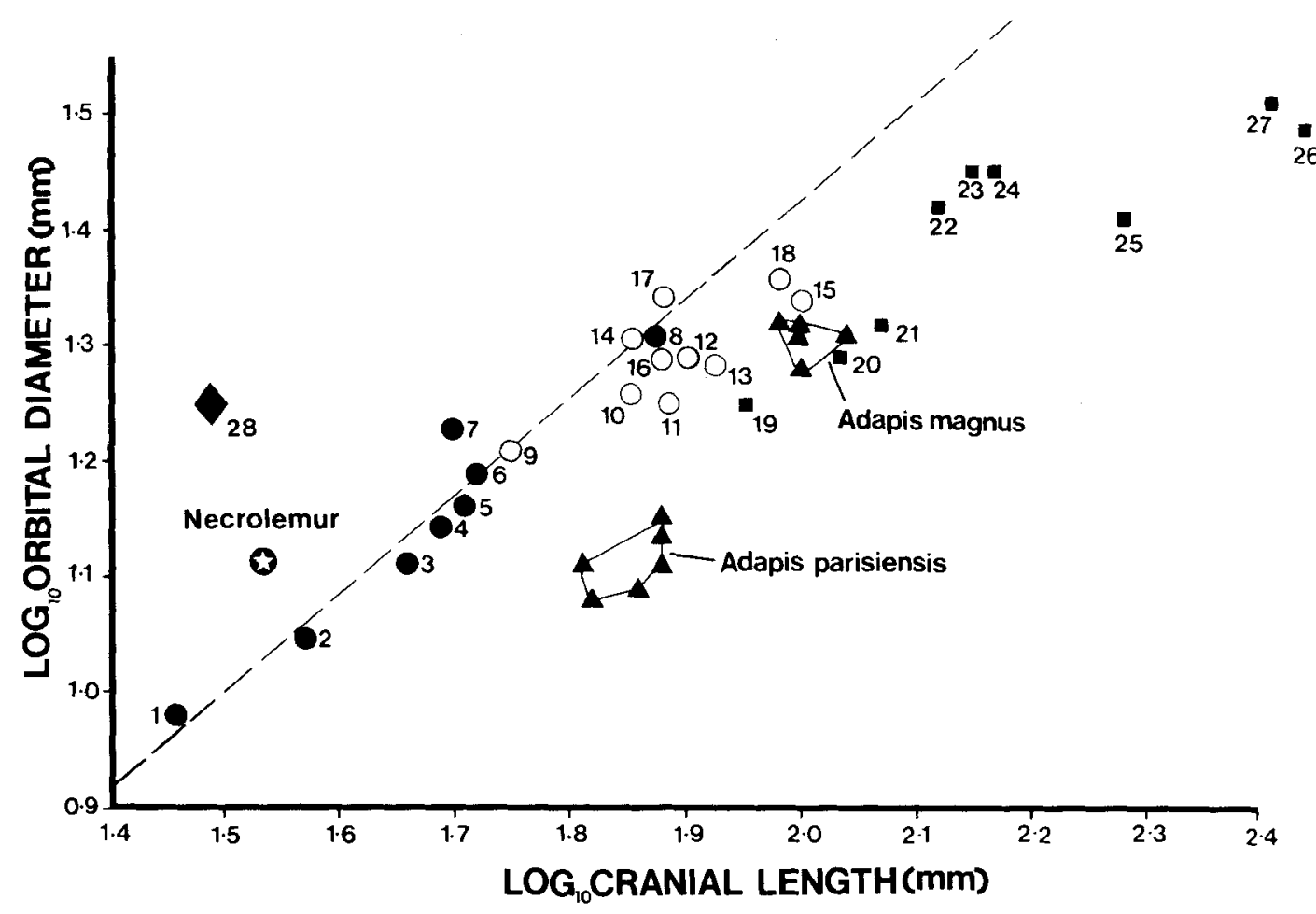

Fig. 6. Relationship between orbital diameter and cranial length in lemurs, Adapis, tarsioids (data for living lemurs and key to their numbering given in Table 4). The dashed line is the major axis for eight definitely nocturnal lemur species (solid circles, no. 1-8): $\log _{10}$ OD $=0.85 \log _{10} \mathrm{SL}$ -0.27 (where OD = orbital diameter; $\mathrm{SL}=$ cranial length, and $r=0.96$ ). With the exception of species of Hapalemur (no. 9 and 14) and Propithecus (no. 16 and 17), diurnal lemurs (open circles, no. 9-18) have smaller orbits than expected from this relationship, and all subfossil lemurs (solid squares, no. 19-27) have distinctly smaller orbits. On the other hand, Necrolemur and especially Tarsius (black diamond, no. 28) have orbits larger than expected. Specimens of Adapis (solid triangles) fall well below the principal axis, suggesting that they were probably diurnal. Key to subfossil lemurs: (19) Mesopropithecus sp., (20) Varecia insignis, (21) Varecia julleyi, (22) Archaeolemur majori, (23) Hadropithecus stenognathus, (24) Archaeolemur edwardsi, (25) Palaeopropithecus ingens, (26) Archaeoindris fontoynonti, (27) Megaladapis sp. 


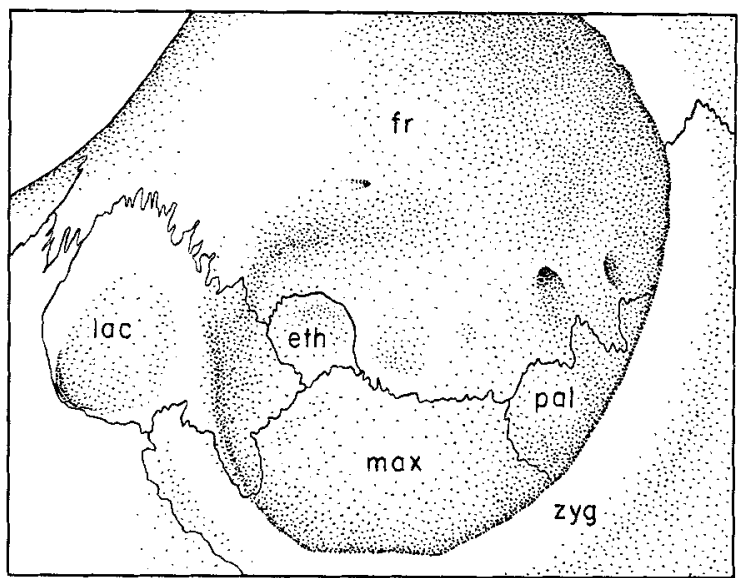

A

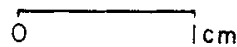

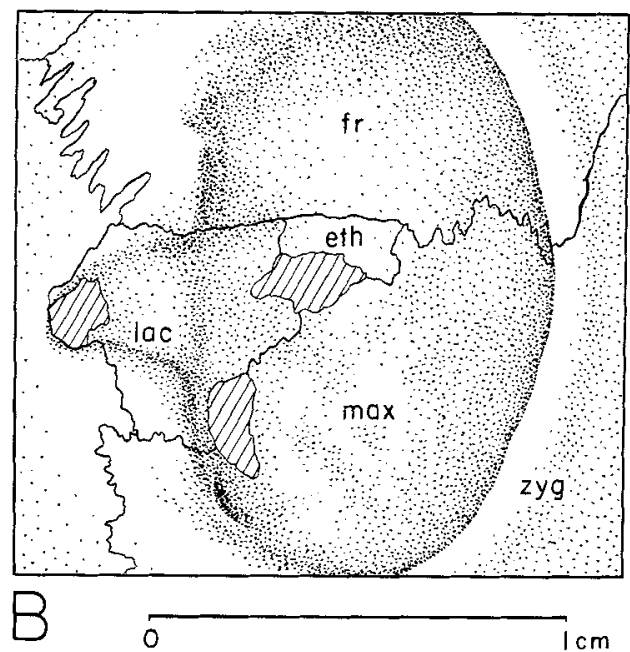

Fig. 7. Comparison of orbital construction in Adapis parisiensis and Indri indri. (A) Indri indri, Leiden Rijksmuseum specimen " $h$," and (B) Cambridge skull of Adapis parisiensis. Note similar relationships of lacrimal, frontal, and maxilla, and the presence in both of an exposed ethmoid "os planum." A bbreviations: eth, ethmoid; fr, frontal; lac, lacrimal; max, maxilla; $\mathrm{n}$, nasal; pal, palatine; zyg, zygomatic.

other exception to the general pattern, although Tattersall (1978) reports that Lemur mongoz can exhibit diurnal habits on one of the Comoro Islands. Walker (1967) made a plot similar to that in Figure 6 but used simple linear coordinates that do not take into account the probable allometric relationship between orbital diameter and cranial length.

There is no clear separation of nocturnal from diurnal lemuroids when orbital diameter is plotted against cranial length on logarithmic coordinates. The best separation of nocturnal and diurnal forms is based on overall body size, but, as noted above, there are exceptions to this. The situation is clarified to some degree by plotting the major axis for the relationship between orbital diameter (OD) and cranial length (SL) for nocturnal forms alone (dashed line in Fig. 6), giving a standard against which diurnal species can be compared

$$
\left(\log _{10} \mathrm{OD}=0.85 \log _{10} \mathrm{SL}-0.27 ; r=0.96\right)
$$

The diurnal Propithecus (no. 16 and 17) and the diurnal/crepuscular Hapalemur species (no. 9 and 14) fall very nearly on the principal axis predicting orbital diameter in large noctural lemurs, but as a group diurnal lemurs fall somewhat below the regression for nocturnal species. In other words, diurnal species tend to have smaller orbits than one would expect in nocturnal species of the same cranial length, but not all lemurs conform to this generalization. Among the nocturnal species, Avahi appears to have exceptionally large orbits, just as Tarsius does. Interestingly, the Eocene tarsioid Necrolemur also has relatively larger orbits than one finds in the average nocturnal lemur, suggesting that Necrolemur, like Tarsius (diamond, no. 28, in Fig. 6), was probably nocturnal. Another Eocene tarsioid, Rooneyia, would fall close to Lepilemur mustelinus (species no. 3) if plotted on the figure, since it has relatively smaller orbits than Necrolemur (Kay and Cartmill, 1977: Fig. 6).

Data on orbital diameter and cranial length for Adapis parisiensis and Adapis magnus are included in Figure 6. Both of these species have significantly smaller orbits than one would expect in a nocturnal lemur of their cranial length, suggesting that both species were probably diurnal. Extinct subfossil lemurs, ranging from Mesopropithecus to Megaladapis are also plotted in Figure 6. All fall well below the regression for nocturnal lemurs, supporting Walker's (1967) suggestion that all were diurnal. However, inferences about activity patterns in the large subfossil lemurs require extrapolation to larger body sizes than are represented by living lemurs, and this conclusion may not be justified (Kay and Cartmill, 1977). 


\section{Orbital construction}

Two features of orbital construction are well preserved in the Cambridge skull of Adapis parisiensis. First, the lacrimal foramen opens on the exposed facial part of the skull. Second, it appears that a small but distinct ethmoid component, or "os planum," is exposed in the medial orbital wall (Fig. 7).

The Cambridge skull shows the lacrimal bone to be moderately extended out onto the face (Fig. 7B). The lacrimal foramen opened at the extreme anterior part of the lacrimal bone, and it clearly opened onto the face as it does in Tarsius and in lemuriform and lorisiform primates, not within the orbit as it does in most anthropoid primates. This observation contradicts that of Forsyth Major (1901) on other Adapis specimens, and Gregory (1920) on Notharctus. Stehlin (1912) observed that considerable variation exists in the placement of the lacrimal foramen relative to the orbital margin in Adapis.

An os planum is characteristic of Tarsius, lorisoids, most lemuroids, and simian primates (monkeys, apes, and humans). Ethmoid exposure in the orbital wall of living primates is thought to be correlated with possession of relatively large orbits, closely approximated orbits, or a combination of both of these characteristics (Cartmill, 1975), but exceptions to this rule exist and Indri is such an exception (Fig. 7A; Cartmill and Gingerich, 1978; Cartmill, 1978). In Indri the ethmoid, when exposed, is located between the lacrimal, frontal, and maxilla.

A distinct ethmoid component appears to be present in the medial wall of the orbit of the Cambridge skull of Adapis parisiensis (Fig. 7B), which is the first evidence of an os planum in an Eocene prosimian. As in Indri, the os planum of Adapis parisiensis is small and located between the lacrimal, frontal, and maxilla. None of the other skulls of Adapis parisiensis or Adapis magnus we have examined appear to preserve an os planum, even though the sutures in this region of the skull are beautifully preserved in some specimens. Thus we conclude that ethmoid exposure in the orbital wall occurs with low frequency in Adapis, as it does in Indri. Given an orbital convergence of about $65^{\circ}$ in Adapis parisiensis, the presence of an os planum in Adapis is consistent with Cartmill's idea that this condition results from narrowing the interorbital region to the point where the periorbital cones impinge on the nasal capsule (Cartmill, 1971, 1978).

Relationships of the lacrimal, frontal, maxilla, and palatine in the orbital wall are clearly shown in the Cambridge skull. Szalay (1976: p. 371) claimed that there is a "broad palatine-lacrimal contact excluding the maxilla from contacting the frontal" in Adapis parisiensis, but the opposite is true. Adapis and Pronycticebus (Le Gros Clark, 1934), likeIndri, have a broad frontal-maxilla contact excluding the palatine from contacting the lacrimal. This adds considerable paleontological weight to the hypothesis that a frontomaxillary contact is the primitive arrangement in primates (Russell, 1964; Cartmill, 1975, 1978). However, caution is needed in accepting such an interpretation for several reasons. Sutures may disappear through fusion in adult skulls and thus become unidentifiable even in modern skull material, making interpretation of unique fossil specimens less certain. The fact that ethmoid exposure in the orbital wall is present in at least someAdapis parisiensis is indicative that there may have been some special relationship between the ethmoid and the orbit in early primates.

The Cambridge skull represents a young adult, and it is possible that the orbital mosaic changed with age. Ethmoid exposure as an os planum is found in all the major groups of primates and it is only among the larger-bodied lemurs that it is consistently or usually lacking. Martin (1968) suggested that ethmoid exposure was present in the common ancestor of the extant primates, and he subsequently emphasized that the ancestral primates were probably quite small-bodied (Martin, 1979). Accordingly, one must also consider the possibility that the relatively large-bodied Adapis and the larger lemurs (i.e., those in excess of 1 $\mathrm{kg}$ body weight) have secondarily undergone partial or complete loss of ethmoid exposure in the orbit. It would be expected, in line with this, that an os planum might be present in young individuals, which are small, and become suppressed with increasing age as they grow larger.

\section{INFRAORBITAL FORAMEN}

The infraorbital foramen has a single opening approximately $0.5 \mathrm{~mm}$ by $1.1 \mathrm{~mm}$ in diameter on the left side in the Cambridge skull, but a double opening, each aperture being approximately $0.5 \mathrm{~mm}$ in diameter, on the right side. The infraorbital foramen in generalized living mammals transmits infraorbital branches of the maxillary nerve and blood vessels supplying the upper lip, rhinarium, and facial vibrissae. When these measurements are added to the graph recently published by Kay and Cartmill (1977: Fig. 7) showing the relative size 

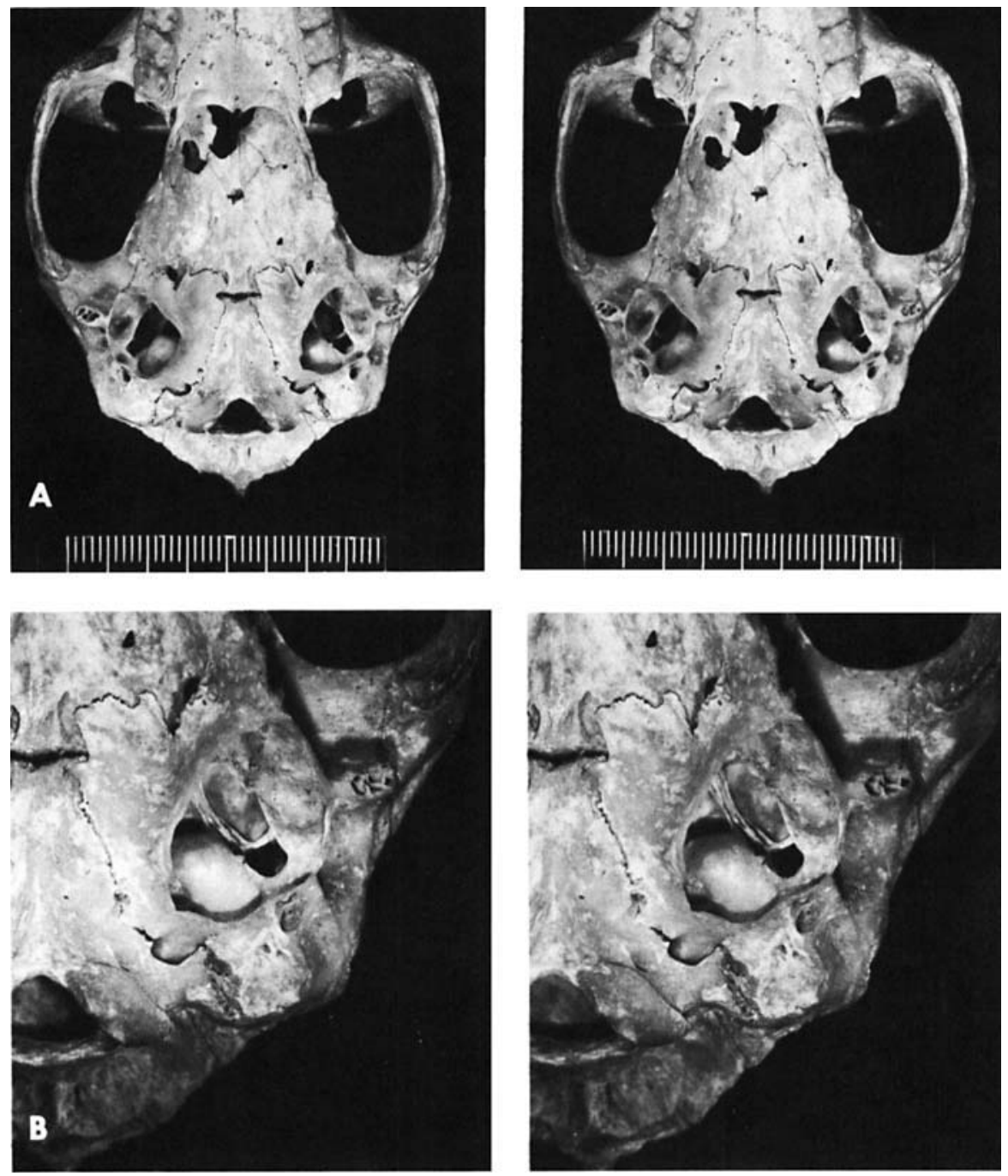

Fig. 8. Stereophotographs of basicranium of Cambridge skull of Adapis parisiensis (M.538). (A) Entire basicranium in ventral view, scale in millimeters. (B) Enlarged view of left auditory region. Free anular ectotympanic within the auditory bulla has been broken away, but other structures are exceptionally well preserved.

of the infraorbital foramen in living mammals, Adapis is seen to have exceptionally small infraorbital foramina. Adapis falls well below living strepsirhine primates, and near the lower limit of relative size of the infraorbital canal in haplorhines as well. This indicates that the rhinarium and facial vibrissae were probably poorly developed in Adapis.

\section{AUDITORY REGION}

The auditory region of Adapis parisiensis is well known as a result of Stehlin's (1912) beau- tifully illustrated descriptions. The basicranial region of the Cambridge skull is illustrated here in Figure 8 . The ectotympanic, known from other skulls of Adapis to be a free ring within the auditory bulla, has been broken away on both sides of the Cambridge skull, and the primary importance of this skull is its pattern of breakage (produced by preparation at some previous time), permitting the internal diameter of the bony canals for the branches of the internal carotid artery to be estimated. These estimates were made from the curvature 

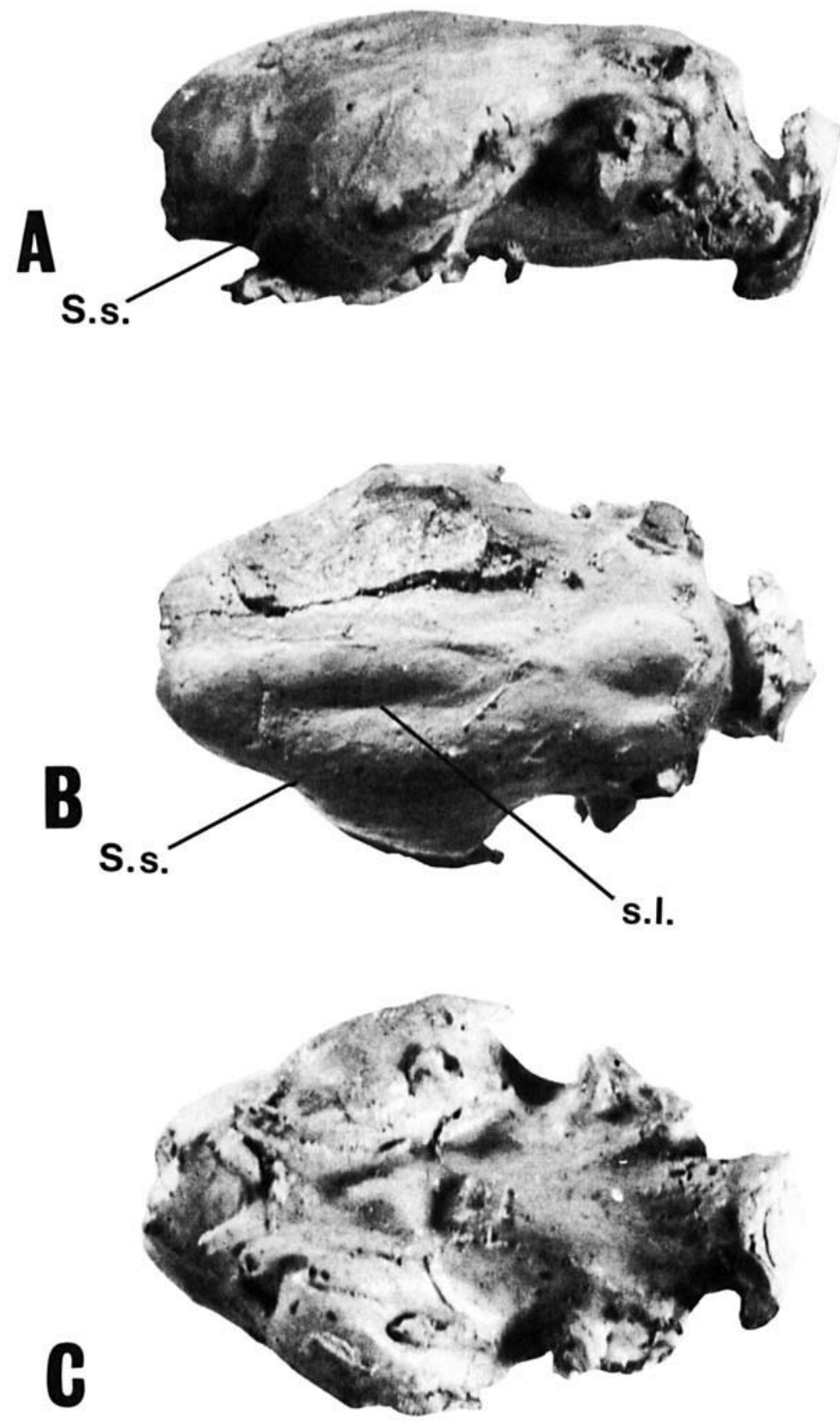

Fig. 9. Photograph of resin cast made directly from the latex endocast of the CambridgeAdapis parisiensis skull. (A) Left lateral view, (B) dorsal view, (C) ventral view. Key: s.l., lateral sulcus; S.s., Sylvian sulcus (see Fig. 9 for more detailed labeling). Approximately $1.5 \times$ natural size. 
of the preserved portions of the canals, since the ventral parts are broken away. The canal for the internal carotid artery is about $0.5 \mathrm{~mm}$ in diameter where it enters the posterolateral corner of the auditory bulla. Once inside, the internal carotid canal divides into two branches, the stapedial branch being about 0.4 $\mathrm{mm}$ in internal diameter, and the promontory branch being about $0.2 \mathrm{~mm}$ in diameter. Thus, in this specimen, the stapedial canal was approximately twice the diameter and four times the cross-sectional area of the promontory canal. The stapedial canal continued on through the stapes, one of which is still in place, in an ossified tube. Most of the promontory canal was not enclosed in a bony tube, but its course is marked by a distinct groove on the promontorium.

The Cambridge skull agrees with a skull of Adapis in Munich, Stehlin's type of Adapis parisiensis schlosseri, in having the internal diameter of the stapedial canal larger than that of the promontory canal. In the Munich skull, however, the stapedial appears to have been only about twice the cross-sectional area of the promontory canal. A third skull, in Leuven, shows the opposite relation in having a stapedial canal with only half the internal cross-sectional area of the promontory canal. In the one specimen of Notharctus (American Museum of Natural History no. 11466) in which the internal diameter of the canals can be measured, the promontory canal is slightly more than twice the cross-sectional area of the stapedial canal (Gingerich, 1973). Thus there is significant variation in the relative sizes of the two branches of the internal carotid canal in adapids. The significance of this variation for primate systematics will not be clear until we have a better understanding of variation in the carotid canals of modern lemuroids. Conroy and Wible (1978) have shown that the promontory canal does not always carry a promontory branch of the internal carotid artery in extant lemuroids, and Hill (1953) found that the stapedial canal in Tarsius does not always house a stapedial branch of the internal carotid artery. These discoveries do not bear directly on the systematic interpretation of fossils, which are based on the canals in any case, but they do affect our interpretation of possible functional differences between the carotid circulatory patterns of various living and fossil prosimians.

\section{BRAIN SIZE AND MORPHOLOGY}

\section{Brain size}

Endocranial casts of the brain of Adapis parisiensis have been known for many years. Neu- mayer (1906), Le Gros Clark (1945), Piveteau (1958), Hofer (1962), Radinsky (1970, 1977), Jerison (1973), and Martin (1973) have all contributed to our understanding of the brain morphology of Adapis. In spite of some attributions to the contrary, virtually all of our previous knowledge of the brain in Adapis is based on British Museum (Natural History) skull M.1345, the endocranial cast of which was first described by Le Gros Clark (1945).

The Cambridge skull of Adapis parisiensis (M.538) has a well-preserved braincase (except for the absence of part of the skull roof in the right temporal region, Fig. 1A), and the interior was neatly prepared by someone in the past. It was therefore possible to make a latex endocast, following the technique used by Radinsky (1968), to reveal major external morphological features of the brain. Because the region of the skull housing the olfactory bulbs is so fragile, it was decided that this area should be sealed off prior to making the latex cast. The resulting latex endocast therefore lacks impressions of the olfactory bulbs, and it is incomplete in the right temporal region. The endocast was allowed to cure and then was used to make a resin cast (Fig. 9), which was subsequently reworked. In order to obtain a reasonably reliable cast of the whole brain, the resin cast was carefully pared down and then reconstructed with modeling clay (Fig. 10). The incomplete right temporal region was reconstructed as a mirror image of the left, while the olfactory bulbs were built up to match the size indicated by $x$-rays (Fig. 11) and by direct examination of the skull. The complete braincast thus obtained permits observations on overall size relative to estimated body size, and on specific external morphological features.

The cranial capacity of a well-prepared skull can be measured directly with a suitable packing material in order to obtain a measure of overall brain size. Martin (1973) measured the cranial capacity of the British Museum (Natural History) skull M.1345 with mustard seed, arriving at a figure of $8.8 \mathrm{~cm}^{3}$. Similarly, the cranial capacity of the Cambridge skull has been measured with small sintered glass particles, giving the same value of $8.8 \mathrm{~cm}^{3}$ (Martin, 1980). However, these figures both exceed the values obtained $\left(8.0 \mathrm{~cm}^{3}\right.$ and $8.1 \mathrm{~cm}^{3}$, respectively) when the two available endocasts are measured by water displacement, which indicates that some shrinkage has occurred during the preparation of both. Hence, a figure of 8.8 $\mathrm{cm}^{3}$ for the cranial capacity of Adapis parisiensis should be taken in conjunction with the previously estimated average body weight of 2.0 

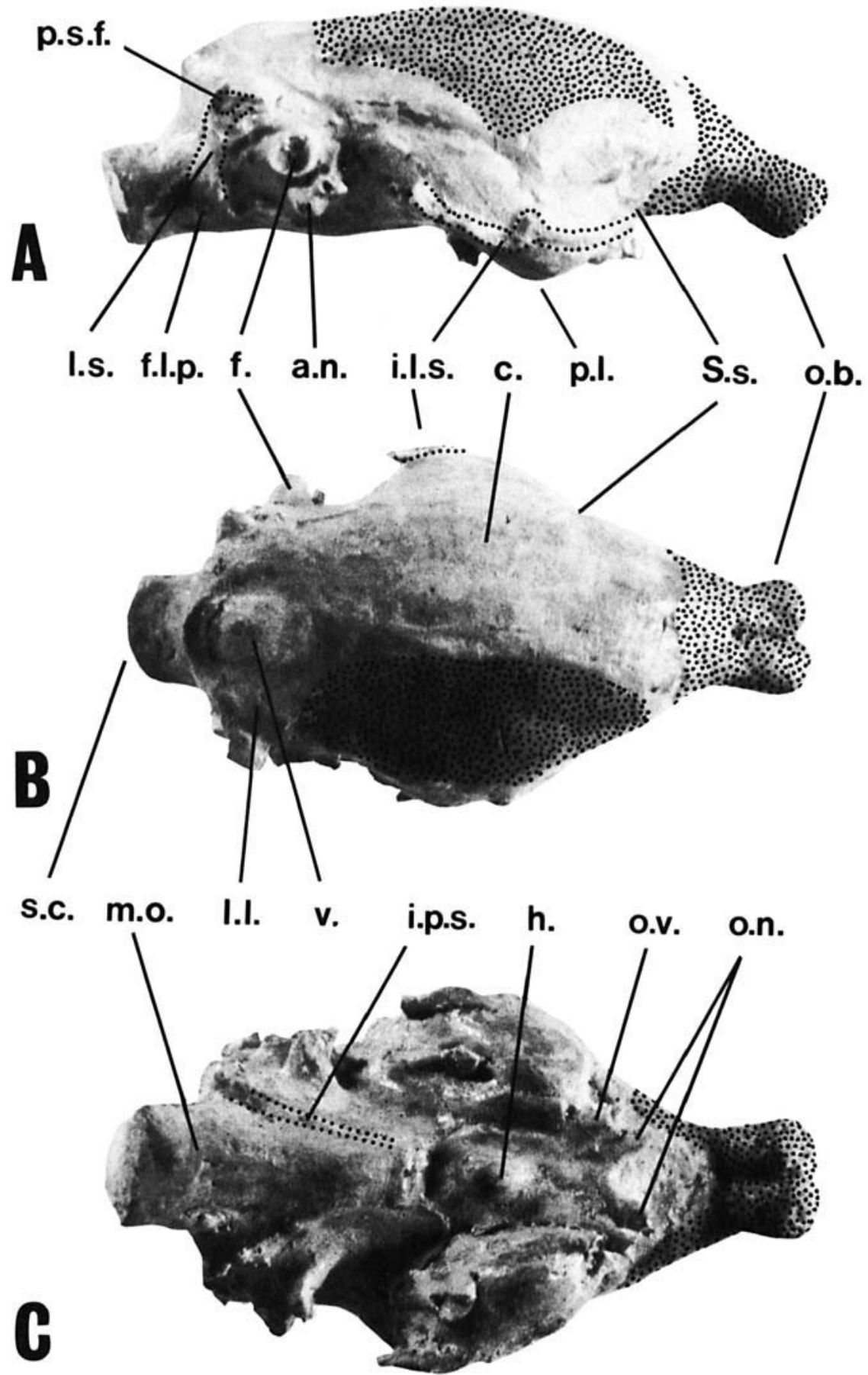

Fig. 10. Reconstructed brain cast of Adapis parisiensis, in (A) right lateral view, (B) dorsal view, (C) ventral view. Reconstructed regions indicated by stippling. Key: a.n., roots of auditory nerve (VIII) and facial nerve (VII); c., cerebral hemisphere; f., flocculus of cerebellum; f.l.p., posterior lacerate foramen transmitting the internal jugular vein, glossopharyngeal nerve (IX), vagus nerve (X), and accessory nerve (XI); h., hypophysis (pituitary); i.l.s., inferior lateral sinus; i.p.s., inferior petrosal sinus; 1.l., lateral lobe of ce- rebellum; l.s., lateral (transverse) sinus; m.o., medulla oblongata; o.b., olfactory bulb; o.n., optic nerve passing to optic foramen; o.v., opthalmic vein, oculomotor nerve (III) trochlear nerve (IV), trigeminal nerve (V), and abducens nerve (VI), transmitted through the anterior lacerate foramen; p.l., pyriform lobe; p.s.f., parietosquamosal foramen S.c., spinal cord; S.s., Sylvian sulcus; v.c., vermis of cerebellum. Approximately $1.5 \times$ natural size. 

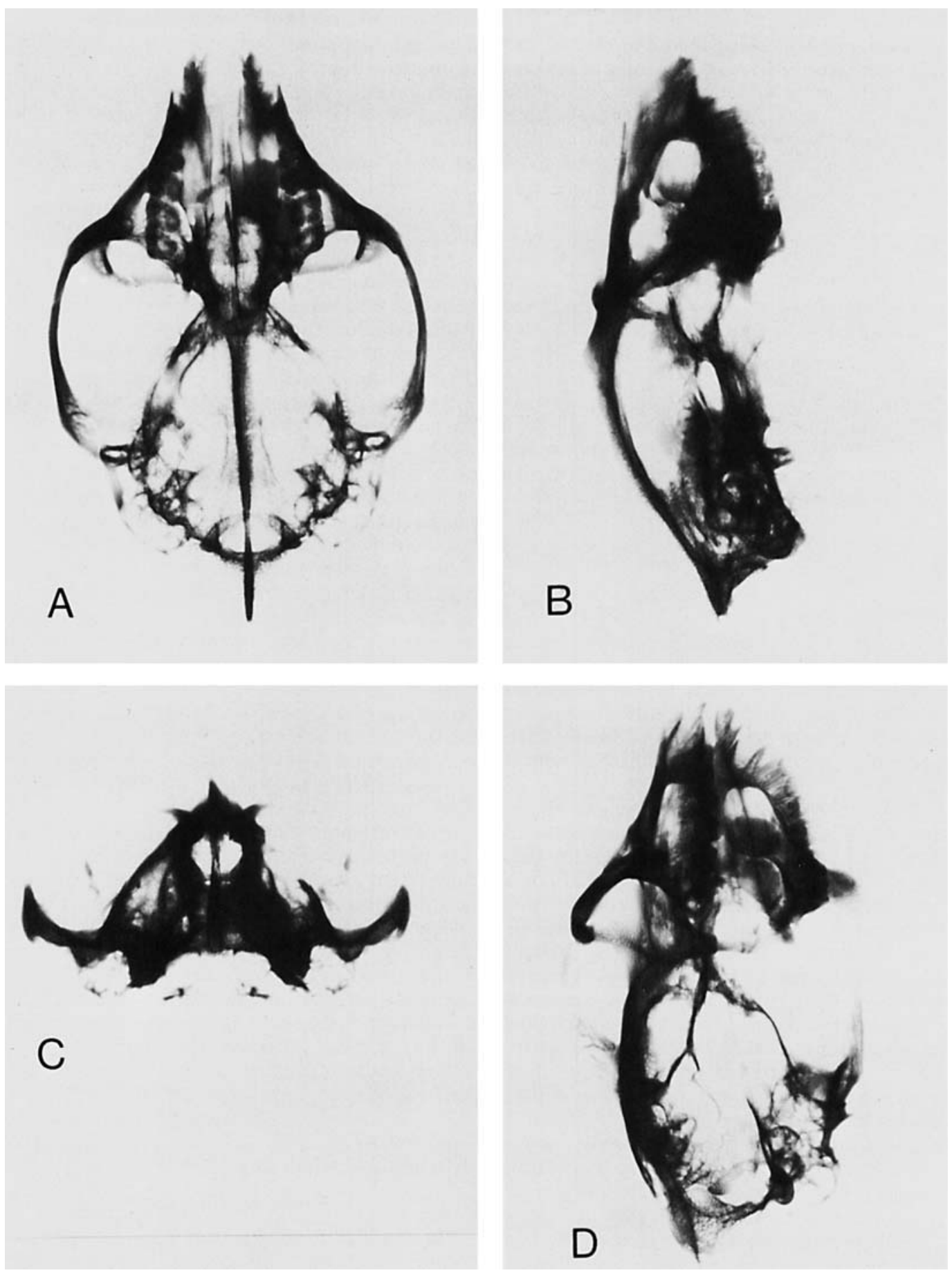

Fig. 11. X-rays of Cambridge Adapis parisiensis skull, in (A) dorsal/ventral view, (B) lateral view, (C) anterior/posterior view, and (D) oblique lateral view. Approximately natural size. 
$\mathrm{kg}$ for examination of relative brain size in this species.

Radinsky (1977) calculated the size of the original Adapis parisiensis endocast as $9.0 \mathrm{~cm}^{3}$ (apparently using water displacement) while Jerison (1973) used double graphic integration to arrive at a figure of $9.6 \mathrm{~cm}^{3}$ (see also Jerison, 1979). Both of these values would appear to be overestimates in light of our new information from the Cambridge skull. Unfortunately, there is no endocast of Adapis magnus available as yet (the endocranial cast of "Adapis magnus" illustrated by Piveteau, 1957, is in fact the Adapis parisiensis cast originally described by Le Gros Clark in 1945).

\section{Encephalization}

Using the approach developed by Jerison (1973), one can compare brain:body size relationships in Adapis with those in living primates and other mammals by calculating an encephalization quotient (EQ) using the following formula:

$\mathrm{EQ}=\frac{\mathrm{CC}}{0.12(\mathrm{BW})^{2 / 3}}$

where $\mathrm{CC}=$ cranial capacity $\left(\mathrm{cm}^{3}\right)$ for a given species, and BW = body weight (gm). It should be noted that Martin (1980) has demonstrated that cranial capacity may be directly equated with brain weight on the basis of an empirical relationship determined for 36 extant nonhuman primate species.

Substituting the values given above into Equation 6, the EQ of Adapis parisiensis is estimated at 0.45 . This value is greater than that of 0.39 calculated by Radinsky (1977), but it is considerably below the values of $0.53-0.58$ determined by Jerison $(1973,1979)$. Since the range of $E Q$ values for living prosimian species $(\mathrm{N}=18$; Stephen et al., 1970) is 0.67 to 1.90 , it is clear that Adapis parisiensis had a smaller brain relative to its body size than do any modern prosimians. Extant Lemur fulvus, with a body weight of $1,400 \mathrm{gm}$, has an $\mathrm{EQ}$ of 1.55 , which is well above that determined for Adapis parisiensis. Thus, when Adapis parisiensis is compared to the most relevant models among living prosimians, medium-sized diurnal lemurs, it is seen to be considerably more primitive in terms of relative brain size.

While considering size relationships, it is again interesting to examine the foramen magnum and, by inference, the caliber of the spinal cord. It has been shown above that use of the empirical relationship between foramen magnum area and body size determined from modern nonhuman primates to predict body weight in Adapis leads to serious underestimation by comparison with estimates from other skull measures (for Adapis parisiensis foramen magnum area suggests a body weight $20 \%$ of that accepted from Table 3, for A. magnus it is only $9-10 \%$ ). If, on the other hand, we take the empirical relationship between cranial capacity $\left(\mathrm{CC}\right.$, in $\left.\mathrm{cm}^{3}\right)$ and foramen magnum area (FA, foramen magnum height in millimeters multiplied by foramen magnum width in millimeters) for a sample of 48 extant nonhuman primate species, we can see whether the cranial capacity of Adapis can be correctly predicted from the following major axis formula:

$\log _{10} \mathrm{CC}=1.69 \log _{10} \mathrm{FA}-2.10 . \quad[r=0.98] \quad$ (7) This relationship indicates a cranial capacity of $8.2 \mathrm{~cm}^{3}$ for Adapis parisiensis, which is $93 \%$ of the accepted value of $8.8 \mathrm{~cm}^{3}$. Hence, when early fossil relatives are included in the picture, the relationship between foramen magnum area and brain size appears to be more consistent than that between foramen magnum area and body size.

An interesting implication of this finding, assuming Adapis parisiensis is representative of Eocene primates, is that the cross-sectional area of the foramen magnum has expanded in line with brain expansion during the course of primate evolution. Unfortunately, we do not know the exact relationship between the caliber of the spinal cord and the area of the foramen magnum. The only published analysis (by Jerison, 1973) was confined to a total sample of four insectivores and prosimians and was based on measurements of scaled photographs of fixed brains with short sections of spinal cord attached that were compared to matching endocasts figured by Bauchot and Stephan (1967). However, it seems likely that there is some fairly close relationship between cross-sectional area of the spinal cord at its origin and foramen magnum area, and it is accordingly likely that during primate evolution expansion of the brain has been accompanied by increase in girth of the spinal cord. For this reason, use of foramen magnum area as an indicator of body size, which is questionable in a comparison limited to extant species, is possibly even less suitable when fossil forms are involved.

\section{Brain morphology}

In addition to the relative size of the brain, other aspects of its morphology are important. The new endocast from the Cambridge skull of Adapis shows a longitudinal lateral sulcus to be well developed (Fig. 9), as Le Gros Clark (1945) originally noted in the British Museum 
specimen. A Sylvian sulcus is present separating the temporal and frontal lobes of the cerebrum in the Cambridge skull, although it is less well marked than in the British Museum specimen. The major difference between the Cambridge and British Museum endocasts is in the relative size of the frontal lobes of the cerebrum. The Cambridge skull itself is undistorted in this area, but careful examination of the original British Museum skull indicates that it is broken and possibly somewhat deformed (impacted) in the frontal region. Therefore the broad flattened appearance of the frontal lobes in the endocast described by Le Gros Clark (1945) may be an artifact of postmortem damage, which would at the same time have accentuated demarcation of the frontal lobes by the Sylvian sulcus (cf. Radinsky, 1970). The Cambridge endocast has smoother and less-expanded frontal lobes than those previously illustrated for Adapis parisiensis.

The new endocast can be compared in detail with a natural endocast of the notharctine Smilodectes gracilis described by Gazin (1965). Labeling in Figures 9 and 10 has been matched as closely as possible to that used by Gazin in order to facilitate comparisons. In both Adapis parisiensis and Smilodectes gracilis, the cerebrum is basically lissencephalic or smooth except for the presence of the lateral sulcus, which is clearly marked in both species. The rhinal fissure marking the division between neopallium and paleopallium was probably located low down on the temporal lobe. Its position is suggested, in both Adapis and Smilodectes, by the presence of a sinus (inferior lateral sinus of Bauchot and Stephan, 1967) running from the cranio-orbital foramen backward to the postglenoid foramen. In modern lemurs the rhinal fissure is usually located at the level of the inferior lateral sinus, which is also found on endocasts of modern lemurs (Radinsky, 1974). This indicates that expansion of the neopallium was already moderately well developed in Eocene adapids, and the temporal lobes are correspondingly quite prominent.

There is moderate backward expansion of the occipital poles of the cerebral hemispheres in Adapis parisiensis and Smilodectes gracilis, where these cover all or most of the mesencephalon but only just touch the cerebellum. In both Adapis and Smilodectes, division of the cerebellum into a central vermis and two lateral lobes can be clearly recognized, and the roots of the flocculi can be identified on either side.

The endocast of Smilodectes gracilis differs from that of Adapis parisiensis in lacking an obvious Sylvian sulcus and in its more globular overall shape, but otherwise the two species resemble each other quite closely. Radinsky (1970) indicates that the olfactory bulbs in Smilodectes are small, while those preserved on the original endocast of Adapis parisiensis (produced by direct casting) are pedunculate and quite large. The olfactory bulbs on the new endocast (reconstructed from x-rays) are also pedunculate and large. When approximate measures of olfactory bulb volume derived from the two Adapis parisiensis endocasts are plotted against body weight, it is found that they fall into the range of modern nocturnal insectivores and prosimians (see Martin, 1979: Fig. 10 ), so there is no indication of a reduction of olfactory bulb size relative to body size in Adapis, despite its apparent adoption of diurnal habits.

Sinus canals are identifiable on the endocasts of both Adapis parisiensis and Smilodectes gracilis. To a large extent, these follow the expected pattern with clearly marked canals over the temporal lobes (as noted above) and identifiable inferior petrosal sinuses and lateral (transverse) sinuses (Fig. 10). In both species, there is a single large foramen on either side of the skull, lying at the junction between the parietal and squamosal bones just anterior to the nuchal crest (see Fig. 3B). These foramina open into well-defined grooves running posteriorly. The endocasts show that on the inside of the braincase the foramina communicate with the upper end of the lateral (transverse) sinus, and it seems likely that in Smilodectes and Adapis there was a large-caliber venous sinus passing through the skull roof at that point. Le Gros Clark (1934) reported similar sinus canals for the European adapid Pronycticebus, and they are equally prominent inAdapis magnus and in species of Notharctus.

In modern prosimians, parietosquamosal foramina are either quite small or completely lacking. In a sample of Hapalemur griseus examined in Leiden, 15 skulls were found to have small emissary foramina exposed in the same approximate position as in Adapis. In one specimen, the foramen is present only on the right side, in another it is present only on the left side, and in a third the foramina are completely lacking. The foramina are usually located between the parietal and squamosal bones, but one specimen of Hapalemur griseus has foramina located well up on the parietals of both sides.

It is difficult to explain the presence of large parietosquamosal foramina in Adapis, beyond noting that they apparently communicate with the lateral venous sinus and that they are 
prominent in all known adapid species. Large parietosquamosal foramina are a primitive trait in a number of mammalian groups, and it is possible that there is some relationship to relative brain size. As brain size increases, rerouting of the contents of the parietosquamosal canals may occur, leading to their declining importance and disappearance. It should also be remembered that species of Adapis had a small foramen magnum, relative to body size, and this may have favored alternative routes for cranial blood vessels. It is at present impossible to be sure what passed through the parietosquamosal canals in adapids, and even assuming that these were occupied by venous blood vessels, it is not clear whether blood would have been flowing into the skull or out of it. If venous blood vessels traversed the parietosquamosal foramina, they may have drained either the brain or an enlarged temporalis musculature.

\section{DISCUSSION}

Adapis parisiensis is among the best-known Eocene primates in terms of its dental and cranial anatomy, although its postcranial skeleton is not yet well known. Because of the lack of reliable evidence about posteranial anatomy, estimates of body weight in both Adapis parisiensis and A. magnus must be derived from skulls and teeth. Comparative analysis of samples of 36-48 modern primate species shows that five different cranial measurements can provide reasonable predictions of body weight $\left(\mathbf{M}^{1}\right.$ length $\times$ width, cranial length, bizygomatic width, internal zygomatic length, and occipital condyle area), although problems may be encountered, especially using skull measurements, when significant sexual dimorphism is present. Taking these five parameters into consideration, we estimate an average body weight of $2.0 \mathrm{~kg}$ for Adapis parisiensis and an average body weight of $8.4-9.0 \mathrm{~kg}$ for Adapis magnus. Males apparently weighed about $20 \%$ more than average, and females weighed about $20 \%$ less than average in each species. Considering their body size alone, it is almost certain that Adapis species were frugivorous and/or folivorous (Kay, 1975). Shearing crests rather than planar grinding areas predominate on the molars of Adapis, indicating that this genus was probably largely folivorous.

The Cambridge Adapis parisiensis skull described here is of special interest for a number of reasons. It is remarkable both in its completeness and in the preservation of numerous clearly marked sutures, despite full eruption of the adult dentition. Previous preparation exposed the inside of the braincase, permitting manufacture of a new endocast that shows relatively less-expanded frontal lobes than the previously described Adapis endocast. Both auditory bullae are also well exposed. Clear preservation of sutures in the medial orbital wall indicates the presence of an ethmoid element or "os planum," previously unreported for any early Cenozoic fossil primate. Work reported separately (Gingerich, 1981) indicates that both Adapis parisiensis and Adapis magnus were sexually dimorphic, and the Cambridge skull is interpreted to represent a male individual.

An average body weight of $2.0 \mathrm{~kg}$ in Adapis parisiensis and a cranial capacity of $8.8 \mathrm{~cm}^{3}$ (based on the endocast described here, as well as that in the British Museum) yields an encephalization quotient $(\mathrm{EQ})$ of 0.45 . This falls within the range of encephalization of progressive Eocene ungulates and carnivores (Radinsky, 1978), but it is clearly below the range established for modern prosimians (0.67-1.90, Stephan et al., 1970). The encephalization quotient of Adapis parisiensis is also well below that estimated for Oligocene Aegyptopithecus (average 0.85, Gingerich, 1977; average 0.690.87 , Kay and Simons, 1980).

Foramen magnum area appears to be more closely related to brain size than to body size when evolution over long periods of time (Eocene-Recent) is considered. Expansion of the brain during primate evolution appears to have been accompanied by expansion of the foramen magnum, which is probably indicative of increasing girth of the spinal cord. The implications of this for increasing locomotor sophistication during primate evolution are considerable but remain to be explored in detail.

The external morphology of the brain of Adapis parisiensis reveals a number of interesting features, many of which parallel those already reported in Smilodectes gracilis (Gazin, 1965). The temporal lobes of the brain are well developed, with the rhinal fissure apparently located well down on the side of the brain. There is a clearly defined lateral sulcus, and the cerebrum overlaps the mesencephalon but not the cerebellum. Adapis and Smilodectes share a similar pattern of sinus canals. One peculiar feature also shared by both, and by all other adapids for which appropriate cranial material is available, is a connection on either side between the dorsal part of the lateral (transverse) sinus and a large parietosquamosal foramen opening into a backward-running groove. No large foramina are found in this position among living primate species, although variable small emissary foramina are present in some genera (e.g., Hapalemur). The func- 
tional importance of this feature of Adapidae is not clear, but there is possibly some connection with the relatively small size of the brain or with the small caliber of the foramen magnum.

The Cambridge endocast of Adapis parisiensis differs from the original British Museum endocast described by Le Gros Clark (1945) in the conformation of the frontal lobes. Comparison of the original skulls indicates that the frontal region of the British Museum skull is crushed slightly, especially on the left side. Accordingly, it would appear that the broad, sharply demarcated conformation of the frontal lobes in the original endocast is an artifact of postmortem damage. Both endocasts of $A$. parisiensis exhibit a true Sylvian sulcus, which is virtually universal among modern primates (Elliot Smith, 1903; Radinsky, 1970; Martin, 1973). This sulcus appears to be lacking in Smilodectes gracilis, however, and it is possible that Adapinae and Notharctinae differ in this respect (a possibility that requires confirmation on endocasts from other species). In addition, it appears that Adapis parisiensis had relatively large olfactory bulbs, whereas Smilodectes gracilis had significantly reduced olfactory bulbs (Radinsky, 1970). Thus, there do seem to be a number of significant differences between adapines and notharctines in brain morphology. Overall, the endocasts of Adapis parisiensis and Smilodectes gracilis indicate that the brains of these Eocene species were primitive with respect to those of virtually all modern primates.

A partial primate skeleton has recently been described from the middle Eocene at Messel, in Germany (von Koenigswald, 1979). This has been assigned to Adapinae on the basis of its size, age, and geographic location, but there is no cranial or dental evidence associated with the specimen that would permit more precise identification. The skeleton indicates that at least one adapine species had grasping feet and calcanei with elongated anterior segments. Adapis is unusual in having a relatively short anterior calcaneal segment (Martin, 1979). A better knowledge of the postcranial skeleton of Adapis would improve our understanding of the adaptations and paleobiology of this genus, but based on present evidence we conclude that Adapis species were medium-sized, visually oriented, diurnal, sexually dimorphic arboreal folivores.

\section{ACKNOWLEDGMENTS}

Thanks are due to Mr. M. J. Meade for skilled preparation of the endocast of the Cambridge skull and for producing a number of casts of the skull. Preparation and conservation work on the skull was carried out by Mr. R. Croucher, who deserves a special note of thanks for his advice and enthusiasm. Photographs of the skull (Figs. 1-3) were prepared by Mr. C. B. Keates of the British Museum (Natural History), while those of the endocasts (Figs. 9 and 10) were made by Mr. T. B. Dennett (Zoological Society of London). Figures 4 and 7 were drawn by Ms. Karen Payne (University of Michigan). Thanks also go to Ms. T. Molleson for preparing an invaluable set of $\mathrm{x}$-rays and for active participation at various stages, to Dr. J. M. M. Rollinson for assisting with the measurements on skulls from living primate species, and to $\mathrm{Mr}$. I. C. Curtis for assistance in the preparation of Figures 5 and 6. Ms. L. Aiello provided much useful advice and stimulating discussion which led to refinement of analysis of allometric relationships.

We also thank Drs. P. Andrews of the British Museum (Natural History), London; D. E. Russell of the Muséum National d'Histoire Naturelle, Paris; A. Cavaillé of the Musée de Montauban, Montauban; L. Thaler and J. Sudre of the Faculté des Sciences, Montpellier; L. van de Poel of the Geologisch Instituut der Katholieke Universiteit, Leuven; and V. Fahlbusch and N. Schmidt-Kittler of the Institut für Paläontologie und Historische Geologie der Universität, Munich, for access to comparative collections of living and fossil primates. We thank Dr. John G. Fleagle, Dr. Leonard B. Radinsky, and Mr. David W. Krause for critical comments improving the manuscript. This research was initiated during tenure of a NATO postdoctoral fellowship at the Universite de Montpellier (to P. D. G.) and completed with support from $\mathrm{Na}$ tional Science Foundation grant BNS 8016742

\section{LITERATURE CITED}

Bauchot, R, and Stephan, H (1966) Données nouvelles sur l'encéphalisation des insectivores et des prosimiens. Mammalia 30:160-196.

Bauchot, R, and Stephan, H (1967) Encéphales et moulages endocraniens de quelques insectivores et primates actuels. Coll. Int. C. N. R. S. Paris 163:575-586.

Berggren, WA (1972) A Cenozoic time-scale--some implications for regional geology and paleobiogeography. Lethaia 5:195-215.

Berggren, WA, McKenna, MC, Hardenbol, J, and Obradovich, JD (1978) Revised Paleogene polarity time scale. J. Geol. 86:67-81.

Cartmill, M (1971) Ethmoid component in the orbit of primates. Nature 232:566-567.

Cartmill, M (1975) Strepsirhine basicranial structures and the affinities of the Cheirogaleidae. In WP Luckett and FS Szalay (eds): Phylogeny of the Primates. New York: Plenum Press, pp. 313-354.

Cartmill, M (1978) The orbital mosaic in prosimians and the use of variable traits in systematics. Folia Primatol. 30:89-114. 
Cartmill, M, and Gingerich, PD (1978) An ethmoid exposure (os planum) in the orbit of Indri indri (Primates, Lemuriformes). Am. J. Phys. Anthropol, 48:535-538.

Conroy, GC, and Wible, JR (1978) Middle ear morphology of Lemur variegatus. Folia Primatol. 29:81-85.

Cray, PE (1973) Marsupialia, Insectivora, Primates, Creodonta and Carnivora from the Headon Beds (Upper Eocene) of southern England. Bull. Br. Mus. Nat. Hist. Geol. 23: 1-102.

Crusafont-Pairo, M, and Golpe-Posse, JM (1975) Les prosimiens de l'Eocène de la région préaxiale pyrénaique. Coll. C N. R. S. Paris 218:851-859.

Cuvier, G (1812) Recherche sur les Ossemens Fossiles. Paris: Imprimerie de Casimir.

Delfortrie, E (1873) Un singe de la famille des lémuriens. Actes Soc. Linn. Bordeaux 29:87-95.

Depéret, C (1917) Monographie de la faune de mammifères du ludien inférieur d'Euzet-les-bains (Gard). Ann. Univ. Lyon 40:1-290.

Elliot Smith, G (1903) On the morphology of the brain in Mammalia, with special reference to that of the lemurs, recent and extinct. Trans. Linn. Soc. (Zool.) Lond. 8:319432.

Forsyth Major, CI (1901) On some characters of the skull in lemurs and monkeys. Proc. Zool. Soc. Lond. 1901:129-153.

Gazin, CL (1965) An endocranial cast of the Bridger middle Eocene primate Smilodectes gracilis. Smithsonian Misc. Coll. 149(4):1-13.

Gervais, P (1873) Remarques au sujet du genre Palaeolemur. J. Zool. Paris 2:421-426.

Gingerich, PD (1972) Molar occlusion and jaw mechanics of the Eocene primate Adapis. Am. J. Phys. Anthropol. $36: 359-368$.

Gingerich, PD (1973) Anatomy of the temporal bone in the Oligocene anthropoid Apidium and the origin of Anthropoidea. Folia Primatol. 19:329.337.

Gingerich, PD (1977) Correlation of tooth size and body size in living hominoid primates, with a note on relative brain size in Aegyptopithecus and Proconsul. Am. J. Phys. Anthropol. 47:395-398.

Gingerich, PD (1981) Cranial morphology and adaptations in Eocene Adapidae. I. Sexual dimorphism in Adapis magnus and Adapis parisiensis. Am. J. Phys. Anthropol. 56:217-234.

Gingerich, PD, Smith, BH, and Rosenberg, K (1981) Allometric scaling in the dentition of primates and prediction of body weight from tooth size in fossils. Am. J. Phys. Anthropol., submitted.

Gould, SJ (1966) Allometry and size in ontogeny and phylogeny. Biol. Rev, 41:487-640.

Gould, SJ (1975) Allometry in primates, with emphasis on scaling and the evolution of the brain. Contrib. Primatol. 5:244-292.

Gregory, WK (1920) On the structure and relations of Notharctus, an American Eocene primate. Mem. Am. Mus. Nat. Hist. 3:49 243.

Hill, WCO (1953) The blood-vascular system of Tarsius. Proc. Zool. Soc. Lond. 123:655-692.

Hladik, CM, and Charles-Dominique, P (1974) The behaviour and ecology of the sportive lemur (Lepilemur mustelinus) in relation to its dietary peculiarities. In RD Martin, RD Doyle, and AC Walker (eds): Prosimian Biology. London: Duckworth, pp. 23-37.

Hofer, H (1962) Über die Interpretation der ältesten fossilen primatengehirne. Bibli. Primatol. 1:1-31.

Hofer, HO (1980) The external anatomy of the oro-nasa region of primates. Z. Morphol. Anthropol. 71:233-249.

Jerison, HJ (1973) Evolution of the Brain and Intelligence. New York: Academic Press.

Jerison, HJ (1979) Brain, body and encephalization in early primates. J. Hum. Evol. 8:615-635.
Kay, RF (1975) The functional adaptations of primate molar teeth. Am. J. Phys. Anthropol. 43:195-215.

Kay, RF, and Cartmill, M (1977) Cranial morphology and adaptations of Palaechthon nacimienti and other Paromomyidae (Plesiadapoidea, ?Primates), with a description of a new genus and species. J. Hum. Evol. 6:19-53.

Kay, RF, and Simons, EL (1980) The ecology of Oligocene African Anthropoidea. Int. J, Primatol. 1:21-37.

Koenigswald, W von (1979) Ein Lemurenrest aus dem eozänen Ölschiefer der Grube Messel bei Darmstadt. Paläont. Z. 53:63-76.

Le Gros Clark, WE (1934) On the skull structure of Pronycticebus gaudryi. Proc. Zool. Soc. Lond. 1934:19-27.

Le Gros Clark, WE (1945) Note on the palaeontology of the lemuroid brain. J. Anat. 79: 123-126.

Maier, W (1981) Nasal structures in Old and New World primates. In RL Ciochon and AB Chiarelli (eds): Evolutionary Biology of the New World Monkeys and Continental Drift. New York: Plenum Press, pp. 219-241.

Martin, RD (1968) Towards a new definition of Primates Man 3:377-401.

Martin, RD (1972) Adaptive radiation and behaviour of the Malagasy lemurs. Philos. Trans. R. Soc. Lond. (Biol.) 264:295-352.

Martin, RD (1973) Comparative anatomy and primate systematics. Symp. Zool. Soc. Lond. 33:301-337.

Martin, RD (1979) Phylogenetic aspects of prosimian behav ior. In CA Doyle and RD Martin (eds): The Study of Prosimian Behavior. New York: Academic Press, pp. 45-77.

Martin, RD (1980) Adaptation and body size in primates. $Z$ Morphol. Anthropol. 71:115-124.

Neumayer, $L$ (1906) Über das Gehirn von Adapis parisiensis Cuv. Neues Jahrb. Min. Geol. Paläont. 2: 100-104.

Petter, JJ, Albignac, R, and Rumpler, Y (1977) Mammiferes Lémuriens (Primates Prosimiens). Faune de Madagascar, O.R.S.T.O.M. et C.N.R.S., Paris 44:1-513.

Petter, JJ, and Peyrieras, A (1970) Observations éco-éthologiques sur les lémuriens malgaches de genre Hapalemur. La Terre et la Vie 24:356-382.

Piveteau, J (1957) Histoire paléontologique des primates. Traité de Paléontologie, Masson, Paris 7:3-214.

Piveteau, J (1958) Recherches sur l'encéphale des primates. I.-L'encéphale d'un prosimien lémuriforme: l'Adapis Ann. Paléontol. 44:253-255.

Radinsky, LB (1968) A new approach to mammalian cranial analysis, illustrated by examples of prosimian primates. J. Morphol. 124:167-180.

Radinsky, LB (1970) The fossil evidence of prosimian brain evolution. In CR Noback and W Montagna (eds): The Primate Brain. New York: Appleton-Century-Crofts, pp. 209-224.

Radinsky, LB (1974) The fossil evidence of anthropoid brain evolution. Am. J. Phys. Anthropol. 41:15-28.

Radinsky, LB (1977) Early primate brains: Facts and fiction J. Hum. Evol. 6:79-86.

Radinsky, LB (1978) Evolution of brain size in carnivores and ungulates. Am. Nat. 112:815-831.

Russell, DE (1964) Les mammiferes paléocenes d'Europe. Mém. Mus. Nat. Hist. Natur. C 13:1-324.

Schilling, A (1970) L'organe de Jacobson du lémurien malgache Microcebus murinus (Miller, 1777). Mém. Mus. Nat. Hist. Natur. A 61:203-280.

Schmidt-Kittler, N (1971) Eine unteroligozäne Primatenfauna von Ehrenstein bei UIm. Mitt. Bayer. StaatssammI Paláontol. Hist. Geol. 11:171-204.

Stehlin, HG (1912) Die Säugetiere des schweizerischen Eocaens: Adapis. Abhandl. Schweiz. Paläont. Gesellsch. 38:1165-1298.

Stehlin, HG (1916) Die Säugetiere des schweizerischen Eocaens: Caenopithecus, etc. Abhandl. Schweiz. Paläont. Gesellsch. 41:1299-1552. 
Stephan, H, Bauchot, R, and Andy, OJ (1970) Data on size of the brain and of various brain parts in insectivores and primates. In CR Noback and W Montagna (eds): The Primate Brain. New York: Appleton-Century-Crofts, pp. 289-297.

Sudre, J (1969) Les gisements de Robiac (Eocène supérieur) et leurs faunes de mammiferes. Palaeovertebrata 2:95156.

Szalay, FS (1976) Systematics of the Omomyidae (Tarsifformes, Primates): Taxonomy, phylogeny, and adaptations. Bull. Am. Mus. Nat. Hist. 156:157-450.

Tattersall, I (1978) Behavioural variation in Lemur mongoz.
In DJ Chivers and KA Joysey (eds): Recent Advances in Primatology, Vol. 3, Evolution. London: Academic Press, pp. 127-132.

Tattersall, I, and Sussman, RW (1975) Observations on the ecology and behavior of the mongoose lemur Lemur mongoz mongoz Linnaeus (Primates, Lemuriformes) at Ampijoroa, Madagascar. Anthropol. Pap. Am. Mus. Nat. Hist. 52:195-216.

Walker, AC (1967) Patterns of extinction among the subfossil Madagascan lemuroids. In PS Martin and HE Wright: Pleistocene Extinctions: The Search for a Cause. New Haven: Yale University Press, pp. 425-432. 